\title{
Trapped in a Metaphor: The Limited Implications of Federalism for Corporate Governance
}

Robert B. Ahdieh

Texas A\&M University School of Law, ahdieh@law.tamu.edu

Follow this and additional works at: https://scholarship.law.tamu.edu/facscholar

Part of the Antitrust and Trade Regulation Commons, Business Organizations Law Commons, Commercial Law Commons, Law and Economics Commons, and the Law and Society Commons

\section{Recommended Citation}

Robert B. Ahdieh, Trapped in a Metaphor: The Limited Implications of Federalism for Corporate Governance, 77 Geo. Wash. L. Rev. 255 (2009).

Available at: https://scholarship.law.tamu.edu/facscholar/1218

This Article is brought to you for free and open access by Texas A\&M Law Scholarship. It has been accepted for inclusion in Faculty Scholarship by an authorized administrator of Texas A\&M Law Scholarship. For more information, please contact aretteen@law.tamu.edu. 


\title{
Trapped in a Metaphor: The Limited Implications of Federalism for Corporate Governance
}

\author{
Robert B. Ahdieh*
}

Trapped in a metaphor articulated at the founding of modern corporate law, the study of corporate governance has-for some thirty years-been asking the wrong questions. Rather than a singular race among states, whether to the bottom or the top, the synthesis of William Cary and Ralph Winter's famous exchange is better understood as two competitions, each serving distinct normative ends. Managerial competition advances the project that has motivated corporate law since Adolf Berle and Gardiner Means-effective regulation of the separation of ownership and control. State competition, by contrast, does not promote a race to either the top or the bottom in shareholder-managerial relations.

Rather than the vertical allocation of wealth between shareholders and managers, state competition is directed to its horizontal allocation between the state and the firm as a whole. Even as state competition shifts surplus from state to firm, thus, it is agnostic as to the distribution of that surplus within the firm. Although it may generate effective rules of corporate law, it is not determinative of the substantive quality of corporate governance. Understood as such, the metrics of "efficiency" in corporate governance-and hence the core inquiries of the corporate law literature-must necessarily shift. Prevailing approaches to questions from the potential utility of federal corporate law to the long persistence of state antitakeover statutes must likewise be reconsidered.

* Professor of Law and Director, Center on Federalism and Intersystemic Governance, Emory University School of Law; Visiting Professor of Law, Georgetown University Law Center; Visiting Scholar, Institute for Advanced Study. My particular thanks go to Fred Tung, for his willingness to tolerate a running series of questions throughout the preparation of this Article. Thanks also to Amitai Aviram, Michelle Bennett, Lisa Bernstein, Mark Brandon, Chris Brummer, Bill Buzbee, Bill Carney, Larry Cunningham, Justin Donoho, Vic Fleischer, Todd Henderson, David Hoffman, Stephanie Holmes, Christine Hurt, David Hyman, Michael Kang, Kurt Kastorf, Bob Lawless, Mark Loewenstein, Henry Manne, Curtis Milhaupt, Marc Miller, Jide Nzelibe, Troy Paredes, Adam Pritchard, Robert Schapiro, Mark Seidenfeld, James Spindler, Randall Thomas, and Liza Vertinsky for their helpful insights, as well as to workshop attendees at the University of Chicago, the University of Illinois, New York Law School, Vanderbilt University, and Washington University, and to my always diligent research assistants. Finally, I am grateful to Princeton University's Program in Law and Public Affairs, for their support of my work on this Article.

February 2009 Vol. 77 No. 2 


\section{Table of Contents}

Introduction ..................................... 256

I. From Two Competitions to One:

Cary, Winter, and the Great "Race Debate" ........ 261

II. Misplaced Metaphor: The Limited Implications of

State Competition for Corporate Governance ........ 268

A. The Distinct Ends of State and Managerial Competition .............................. 269

B. A Reinforcing Role for State Competition in Corporate Governance? ...................... 274

C. State Competition as Cost Savings............ 278

III. Federalism, State Competition, and the Horizontal Project of American Corporate Law............. 280

IV. After the Race: The Implications of Two Competitions in Corporate Law ........................... 290

A. Efficient Markets, Managerial Competition, and Federal Corporate Law .................... 292

B. Understanding the Inefficiencies of State Antitakeover Statutes....................... 299

Conclusion .................................. 302

\section{Introduction}

The study of corporate law is trapped in a metaphor. For thirty years, it has taken its cue from the purported debate between William Cary and Ralph Winter over a "race to the bottom" versus a "race to the top" in corporate governance. ${ }^{1}$ As commonly recounted, Cary initiated the debate, condemning the nature of corporate law as state law. Because of the latter, he argued, states have joined in a "race for the bottom" in the protection of shareholders against managerial abuse. ${ }^{2}$ Winter's response is put to service in support of the opposite conclusion: state law offers precisely what shareholders want. Rather than a race to the bottom in the quality of corporate governance, federalism in corporate law-and resulting state competition-fosters a "race to the top."

1 See William L. Cary, Federalism and Corporate Law: Reflections Upon Delaware, 83 YALE L.J. 663, 663, 705 (1974); Ralph K. Winter, Jr., State Law, Shareholder Protection, and the Theory of the Corporation, 6 J. LeGAL STUD. 251, 255-56 (1977).

2 See Cary, supra note 1, at 666.

3 Perhaps tellingly, Winter's original contribution to the "debate" included no such statement. As we will see, only in later work did Winter reference a "race to the top"-and soon thereafter, back away from that suggestion. See infra note 51 . 
In reality, Cary and Winter agreed on far more than they disagreed. ${ }^{4}$ To date, however, a distorted account of their differencesand the "race" metaphor said to capture their respective positionscontinues to provide the starting point for the study of corporate law. The existence, direction, and speed of the supposed race among states in corporate governance thus remain foundational questions of the corporate law literature.

Here, I suggest that the discourse of a "race" in corporate governance-like many a misplaced metaphor-has obscured at least as much as it has revealed. 5 At once, it has caused us to overstate the centrality of state competition to efficient corporate governance and to understate the distinct normative ends that state competition promotes. ${ }^{6}$

Rather than the singular dynamic of state competition emphasized by the supposed "race debate," we do better to understand Cary and Winter as having highlighted two distinct patterns of competition in the operation and regulation of the modern public corporation. The first, of course, is the competition among states to attract corporate charters. The significance of such competition can be seen as Cary's critical insight. ${ }^{7}$ A distinct dynamic of competition also plays out among managers, however, for scarce investment capital. The relevance of the latter was the innovation (first posited in the legal literature by Henry Manne) that Winter effectively popularized. ${ }^{8}$

In the corporate literature's singular emphasis on a race among states, these two competitions have been merged into one. More significantly, in the standard account of corporate scholars today-i.e., a belief in some movement toward the top, if not necessarily a highspeed race that actually gets there-the distinct normative ends

4 See infra Part I.

5 Cf. Mark J. Loewenstein, Delaware as Demon: Twenty-Five Years Afier Professor Cary's Polemic, 71 U. Colo. L. Rev. 497, 501 (2000).

6 See infra Parts II, III.

7 See Cary, supra note 1, at 665-66.

8 See Winter, supra note 1, at 263-67; see also Henry G. Manne, Our Two Corporation Systems: Law and Economics, 53 VA. L. Rev. 259, 260 (1967); Henry G. Manne, Mergers and the Market for Corporate Control, 73 J. Pol. ECon. 110, 112 (1965); Henry G. Manne, Some Theoretical Aspects of Share Voting, 64 CoLum. L. Rev. 1427, 1430 (1964). To be clear, I do not mean to claim that patterns of managerial and state competition are unrelated. My point is simply that they are distinct in important respects and deserve to be analyzed as such. Most critically, they point corporate law literature in different directions: if shareholder-managerial relations are our priority, then efficiency in the capital markets and resulting managerial competition should be our focus. Alternatively, if we embrace the relations of state and firm as the critical agenda of corporate law, then a continued focus on federalism and state competition is in order. 
served by state and managerial competition have been collapsed. If states are competing in ways that advance the interests of managers, and managers are competing in ways that advance the interests of shareholders, the standard account implicitly suggests, we can simply drop managers out of the middle. With this bit of New Math, we arrive at the conventional wisdom of the modern literature, in which states compete in ways that advance the interests of shareholders. 9

When we maintain the distinction between state and managerial competition lost in the prevailing metaphor of a "race," however, we see a very different picture. If corporate scholars are right to embrace Winter's account of managerial competition-and the efficient capital markets that stand behind it-state competition's implications for corporate governance prove quite limited. Federalism, and resulting state competition, should not be expected to generate any enhancement in the substantive quality of corporate governance, beyond that dictated by the operation of efficient capital markets. ${ }^{10}$

To be more precise: If the capital markets work, competition among states should not be expected to alter the balance of power (and resources) between shareholders and managers that is dictated by competition among managers. Federalism cannot, in a sense, get ahead of the market. In fact, it has no reason to do so. Properly understood, state competition is entirely agnostic as to the ends it advances in corporate governance; it can facilitate managerial rent extractions as effectively as it can increase shareholder power. Whatever substantive efficiency is to be found in American corporate governance, then, is properly traced to managerial competition for capital, rather than state competition for corporate charters. ${ }^{11}$

9 This reductionist move might be tied to the modern rejection of earlier scholars' equation of the distinct goals of shareholder protection and maximization of shareholder wealth. Winter thus highlighted the ways in which heightened shareholder protection might actually decrease shareholder wealth. See Winter, supra note 1, at 258-62. Here, I emphasize a related, but different point: state competition's improvement of the quality of state law may potentially increase the wealth of the modern public corporation. It may do nothing, on the other hand, to protect shareholders against managerial abuses-including managers' potential expropriation of the full value of any improvements in state law. As to each of these ends, competitive mechanisms of efficiency can be found in the operation and regulation of the modern public corporation. But those mechanisms are quite distinct. One lies in the nature of American corporate law, and the other in the efficient markets of American corporate finance.

10 As I emphasize in Part III, this claim should not be understood as a condemnation of federalism or an argument for federal-level rules of corporate governance. Rather, my argument seeks to highlight federalism's true place in corporate law-as both more and less than what the conventional discourse would suggest.

11 It is no answer that federalism is necessary, but insufficient, to advance the substantive 
The normative project to which state competition is directed, thus, is not the risk of managerial failure that motivated Adolf Berle and Gardiner Means ${ }^{12}$ as they stood at the cusp of the New Deal and the birth of the administrative state. ${ }^{13}$ Federalism does not speak to the allocation of corporate surplus between shareholders and managersthe internal division of the corporate pie. ${ }^{14}$ It is not, as such, about the separation of ownership and control. Rather, it is directed to the distinct possibility of regulatory failure-what might be thought of as the perfect counterpoise to the concerns that motivated Berle and Means. ${ }^{15}$

Some will dismiss the foregoing as mere semantics. Few, they will insist, would question my bifurcated account of competition: that is precisely the point of the modern account of corporate law. In this perspective, the shorthand of the "race debate" is simply that-a shorthand fully compatible with the twin dynamics of competition I describe. Self-evident as it may appear, however, an analytical framework of distinct competitions among states and among managerseach serving distinct normative ends-counsels important adjustments in the standard analysis of the corporate literature today.

For the majority of corporate law scholars, who see corporate governance as generally efficient - in the sense that it rests on some gradual advance in the direction of the top-the analysis herein em-

quality of American corporate governance. My argument is that it is not-at least in absolute terms-necessary either.

12 See Adolf A. Berle, Jr. \& Gardiner C. Means, The Modern Corporation and Private Property 84, 115, 128-40 (1932).

13 See infra text accompanying notes 102-04. As the above discussion makes clear, my emphasis herein is on the large, publicly held companies that stand at the center of the theoretical analysis of modern corporate law, as distinguishable from the array of distinct corporate entities to which the standard account, and hence my critique of the latter, speak less directly.

14 Cf. Bernard S. Black, Is Corporate Law Trivial?: A Political and Economic Analysis, 84 Nw. U. L. REv. 542, 577 (1990) (implicitly distinguishing legal changes' role in "enlarging the pie" versus "transfer[ring] wealth from managers to shareholders"). Tangentially to the analysis herein, I would characterize the corporate federalism literature-with its primary focus on interstate competition-as directed to the horizontal dimensions of federalism. It can thus be distinguished from the mainstream federalism literature, which has focused primarily on the vertical dimensions of federalism - the allocation of power between federal and state authorities. Given as much, I believe that closer engagement across those literatures promises synergies for each.

15 My argument, thus, is not that state competition is irrelevant to the modern public corporation. Nor do I predict any necessary race to the bottom, notwithstanding the corporate literature's general resistance to agnosticism on the "race debate." See, e.g., Roberta Romano, Is Regulatory Competition a Problem or Irrelevant for Corporate Governance?, 21 OXFORD REv. ECON. Pol'y 212, 229 (2005). Here, I reject a dichotomous choice between top and bottom. Although I question assertions of a state competition-driven race to the top. I do not predict a race to the bottom. 
phasizes that it is not federalism and state competition that deserve credit for that result, but efficient capital markets and the resulting pressure on managers to compete. State competition may well enhance the facial quality of corporate law-the quality of the rules as rules-but it cannot improve the substantive quality of corporate governance. ${ }^{16}$ Implications likewise follow for those scholars who question the quality of modern corporate governance. For such dissenters from the conventional wisdom, the crucial targets for critique are not the standard bogeymen of federalism and state corporate law. Rather, it is the efficiency of the capital markets to which their challenge must primarily run.

If the quality of corporate governance is determined by efficient markets rather than efficient competition among states, then, a distinct approach to evaluating the efficiency of both corporate governance and state competition is in order. In the heated debates over the adoption of federal rules of corporate governance and the persistence of inefficient state antitakeover statutes notwithstanding state competition, a discourse attentive to the distinct normative ends of state versus managerial competition highlights a more complex set of questions than the existing literature would seem to suggest. ${ }^{17}$

More broadly, by attending to distinct patterns of state and managerial competition, the role of federalism in corporate law becomes something worth talking about. In the prevailing account of the literature, deviations from state competition are presumptively suboptimal. There is little need to evaluate the precise contents of the SarbanesOxley Act of 2002, for example. ${ }^{18}$ It is enough to know that it was adopted by Congress, rather than the State of Delaware. ${ }^{19}$

Properly understood, however, federalism is no more than an institutional design choice, to be assessed like any other. ${ }^{20}$ The choice of federalism and state competition may well be justified in some-and perhaps even most-cases, by comparison with the obvious alterna-

16 See infra Part II.

17 See infra Part IV.

18 Sarbanes-Oxley Act of 2002, Pub. L. No. 107-204, 116 Stat. 745 (codified in scattered sections of $11,15,18,28$, and 29 U.S.C.).

19 See Robert B. Ahdieh, From "Federalization" to "Mixed Governance" in Corporate Law: A Defense of Sarbanes-Oxley, 53 BuFf. L. Rev. 721, 721 (2005).

20 One might plausibly cite Ralph Winter's reply to Cary in support of this contrarian claim of a limited (and elective) role for state competition in American corporate governance. That the embrace of efficient capital markets does not dictate a concomitant embrace of federalism is suggested by state competition's fairly tangential place in Winter's actual analysis, as distinct from his rhetoric. See Winter, supra note 1, at 261-62. 
tive of national rules. But that choice-like the contrary choice to adopt national rules in a given sphere of corporate law-should enjoy no fixed presumption. It should be evaluated and rationalized within the distinct political economy surrounding any given question of corporate law. ${ }^{21}$

In Part I, I lay the groundwork for what follows, describing the conventional distillation of Cary and Winter's exchange in the "race debate," and the actual dynamic of two competitions rather than one to be found in their analyses. Part II challenges the standard account of the corporate law literature, derived from the collapse of state and managerial competition into one: the widely accepted notion that state competition has direct implications for shareholder-managerial relations. Any efficiency gains in the substantive quality of such relations, I argue, are properly traced to managerial rather than state competition. State competition, I suggest in Part III, should instead be understood to foster efficiency in the horizontal relations between the state and the firm as a whole. Implications of this approach are considered in Part IV, where I explore the possibility of federal corporate law and the efficiency implications of the persistence of state antitakeover statutes. To conclude, I suggest the challenge that my analysis presents to the prevailing discourse of corporate law today.

Rather than endorsing a race to the bottom or to the top, what follows posits that the metaphor of a "race" has misled us, leading us to ask the wrong questions and thereby generating unhelpful answers. In place of that metaphor, I suggest a distinct framework for analysis of the central questions facing the modern public corporation. Within the confines of this Article, I do not attempt to derive conclusive answers from that framework regarding the consequences of state competition, the wisdom of national rules of corporate governance, the implications of state antitakeover statutes, or the like. By asking a distinct set of questions, however, we might hope to ultimately generate more satisfying answers.

\section{From Two Competitions to One: Cary, Winter, and the Great "Race Debate"}

The modern study of corporate law centers on the linkage of the most prominent feature in its institutional design-federalism and resulting state competition-and the project that has animated it since

21 There is, as such, no necessary institutional implication of a belief in capital market efficiency. The latter can equally be reconciled with corporate scholars' prevailing commitment to federalism in corporate law or with an opposing desire to federalize corporate law. 
Adolf Berle and Gardiner Means's seminal study of The Modern Corporation and Private Property: effective regulation of the separation of ownership and control. ${ }^{22}$ Stephen Bainbridge thus posits that "competition for corporate charters deters states from adopting excessively pro-management statutes." ${ }^{23}$ The seminal work of Frank Easterbrook and Daniel Fischel, to similar effect, counsels that "[c]ompetition among states does not eliminate the possibility of opportunistic behavior but imposes a constraint." 24

In its origins, this linkage of state competition to the relations of shareholders and managers can be traced to the work of William Cary. A former chair of the Securities and Exchange Commission, Cary posited a direct connection, asserting that state competition drives a "race for the bottom" in the protection of shareholders against managerial abuse. ${ }^{25}$ States covet franchise tax revenues generated by local incorporations-as well as the business such incorporations generate for local interest groups. ${ }^{26}$ They can consequently be expected to modify state law, so as to maximize its attraction to those who might incorporate within the state. ${ }^{27}$ Because managers are the functional decisionmakers as to incorporation, in turn, states will predictably offer increasingly greater discretion to managers, at the expense of shareholders. ${ }^{28}$

Cary's critique received widespread-and largely positive-attention. Prominently, the American Bar Association convened a conference to discuss the article and its policy prescriptions. ${ }^{29}$ Yet it did not go unchallenged. Most notable was the response offered by thenprofessor and now Judge Ralph Winter ${ }^{30}$-a response which laid the foundation for the modern study of corporate law, yet which has been

22 BERle \& MEANS, supra note 12, at 5-6. I do not, it bears noting, mean to suggest that the existing corporate literature is exclusively directed to questions of state competition and the separation of ownership and control. By any fair accounting of the field's seminal works and the emphasis of each passing year's new scholarship, however, its central focus would appear to lie in just those questions. Cf. infra notes 55-56.

23 Stephen M. Bainbridge, Director Primacy and Shareholder Disempowerment, 119 HARV. L. Rev. 1735, 1736 (2006); see also id. at 1742 ("Th[e] process of competitive federalism tends to produce those laws preferred by investors.").

24 Frank H. Easterbrook \& Daniel R. Fischel, The Economic Structure of CorPORATE LAW 222 (1991).

25 See Cary, supra note 1, at 666.

26 See id. at 668.

27 See id. at 663-68.

28 See id. at 665-68.

29 See Winter, supra note 1 , at 255 n.15.

30 See id. at 254-58. 
critically mischaracterized by the corporate literature that has followed.

Contrary to our modern obsession with a Cary-Winter "debate," Winter is properly understood to have affirmed Cary's analysis-as far as it went. ${ }^{31}$. Winter did not dispute the dynamic of state competition suggested by Cary, as either a theoretical or an empirical matter. Nor did he question Cary's assertions that managers were the critical decisionmakers in determining place of incorporation, and that states should consequently be expected to cater to managerial demand. Winter did not even dispute Cary's observation of declining levels of shareholder protection.

For Winter, as such, Cary's error did not lie in anything that he observed about state competition, but rather in his inattention to a distinct pattern of competition playing out in the background. ${ }^{32}$ Winter insisted that managers, given their need to compete for scarce investment capital and to secure their positions by maximizing the return on such capital, were fully incentivized to promote shareholder interests. $^{33}$ As a result, Cary's ultimate prediction could be dismissed. In light of managerial competition, state competition ought not be expected to drive a race to the bottom in shareholder interests. ${ }^{34}$

Cary can be understood, then, as having described a pattern of competition among states that is directed to the demands of managers. As now widely accepted, including most enthusiastically by Cary's detractors, states are anxious to compete for the charter business of public corporations. ${ }^{35}$ Such incorporations bring both increased franchise tax revenues to the state ${ }^{36}$ and increased business to the local bar. ${ }^{37}$ To excel in this competition, states must respond to the demands of

31 Some of the perception of sharp disagreement can be traced to the tone of Winter's response, which was admittedly quite dismissive of Cary's claim. See, e.g., id. at 257 ("That the impact of a legal system on investors would be known only to law professors and Mr. Nader seems a rather tenuous proposition."). When one goes beyond tone and considers the substance of his argument, however, one finds that Winter is largely in agreement with Cary.

32 See id. at 263-66.

33 See id.

34 Again, Winter did not dispute that the legal protections of shareholders might decline. See id. at 259. For Winter, however, this was not "the bottom." Rather, any such decline should be understood as a product of shareholders' willingness to grant managers wider discretion in hopes of securing higher returns. See id.

35 See Cary, supra note 1, at 665 ("In all fairness it should be noted that if Delaware had not entered the race, other states would have joined in to attract the lucrative business of incorporating.").

36 See id. at 668 ("[T]he raison d'etre behind the whole system has been achieved-revenue for the state of Delaware.").

37 See id. ("With some justification Delaware corporate counsel take pride in their role 
managers, the functional decisionmakers in determining place of incorporation. ${ }^{38}$ States can thus be understood to be in a competition to supply a package of rules, institutions, and taxes that best meets managerial demand. ${ }^{39}$

Winter responded by highlighting a distinct dynamic of competition-one among managers to meet the demand of shareholders. As earlier posited by Henry Manne, but popularized by Winter, ${ }^{40}$ managers should be understood to compete within three intertwined markets: first, the capital markets and, extending from them, the product markets (i.e., the market for the firm's goods and services) and the market for corporate control (i.e., potential takeover of the firm and displacement of inefficient managers). ${ }^{41}$ Operating at the nexus of these markets, managers are forced to compete-both with one another and vis-à-vis other investment opportunities-to provide both corporate governance and investment returns that meet the demand of existing and potential shareholders. ${ }^{42}$ Given such competition,

and enjoy the fees that flow from it. The system 'engenders a volume of business for the bar which tends to be regarded as a vested interest ....'").

38 See id. at 665-66; see also Gillian Hadfield \& Eric Talley, On Public Versus Private Provision of Corporate Law, 22 J.L. Econ. \& Org. 414, 415 (2006); Marcel Kahan \& Ehud Kamar, The Myth of State Competition in Corporate Law, 55 STAN. L. Rev. 679, 681 (2002).

39 My reference to states' attention to managerial demands is not intended to suggest that this necessarily comes at shareholders' expense. I am not staking out a position, thus, on whether state competition leads to the bottom or the top. Instead, as will become clear, I believe that both advocates and critics of state competition should acknowledge its orientation to managerial demands. The entirely separate, and critical, question for corporate governance is whether managerial demands are aligned with shareholder interests.

40 See supra note 8 and accompanying text.

41 See Winter, supra note 1, at 263-64. Winter states that:

The fact that shareholders generally, and major institutional investors in particular, find little need for "control" strongly suggests that forces other than formal legal structure profoundly shape corporate performance and provide substantial protection for shareholders. If the law of corporate governance is to make sense, it must take into account the constraints these forces impose on the parties to corporate transactions. These constraints arise largely from competition in two markets which interact with each other and with the capital market: (1) the market for products and services and (2) the market for management control.

Id. In Winter's precise construction, thus, two of the relevant markets-the products markets and the market for corporate control-were characterized as interacting with the third-the capital markets. See id. Other nonregulatory mechanisms of managerial constraint, it bears noting, have also been identified. See, e.g., Daniel R. Fischel, The "Race to the Bottom" Revisited: Reflections on Recent Developments in Delaware's Corporation Law, 76 Nw. U. L. Rev. 913, 918-20 (1982) (noting constraints including managers' oversight of their fellow managers, as well as compensation mechanisms by which managers "share the risk bearing function with shareholders").

42 Elaborating Winter's argument slightly further, competition with one's counterparts in the products market requires efficient management of the relevant enterprise and resulting effi- 
Winter argued, the agency costs attendant to the separation of ownership and control were limited, and Cary's worries about a race to the bottom were unwarranted. ${ }^{43}$

This analysis required no endorsement or embrace of state competition. State competition was irrelevant to it. Winter's story was not one of federalism, as such, but of markets. One would hardly guess as much, however, judging by the modern corporate literature. Even as the study of corporate law has embraced the economic approach underlying Winter's analysis, it has elided his distinct emphasis on managerial competition. Instead, in the thirty years since publica-

ciency in pricing, as well as access to capital for purposes of modernization and innovation. The former can be expected to constrain management extractions manifested in product pricing. See Winter, supra note 1 , at 264 . The latter forces managers to face the capital markets. See id. at 262-66; see also id. at 264-65 ("Professor Henry Manne has written a series of articles arguing that share price and the capital market exert discipline on the behavior of corporate management. The body of his work has yet to be seriously confronted by corporate critics, much less weakened."). The cost of capital varies widely, of course, in accordance with its relative security. Corporations subject to lax management control-or, to be more precise, a less-than-optimal degree of managerial discretion-can thus be expected to pay more to secure funds than competitors operating under rules more valued by shareholders and creditors. See id. at 257 . Winter states that:

Management must induce investors freely to choose their firm's stock instead of, among other things, stock in companies incorporated in other states or other countries, bonds, bank accounts, certificates of deposit, partnerships (general or limited), individual proprietorships, joint ventures, present consumption, etc. . . [A] corporation's ability to compete effectively in product markets is related to its ability to raise capital, and management's tenure in office is related to the price of stock.

Id.

Whether a product of default rules of the state of incorporation, or explicitly built into the corporate charter or bylaws of a particular firm, governance rules favoring managers over shareholders-agency failures and attendant costs-can thus be expected to hurt managers as much as shareholders. Of course, such an analysis must depend on a repeat player dynamic in corporate finance, such that managers expect to return to the capital markets subsequent to any deviation from optimal rules. Such an assumption is not especially heroic, however, in the case of the modern public corporation. $C f$. id. ("If management is to secure initial capital and have continuous access to ready capital in the future, it must attract investors away from the almost infinite variety of competing opportunities.").

Further policing managerial behavior is the market for corporate control. Here, Winter highlighted that suboptimal managerial performance creates opportunities for arbitrage. See id. at 265-66; see also Ronald J. Gilson, A Structural Approach to Corporations: The Case Against Defensive Tactics in Tender Offers, 33 STAN. L. REv. 819, 841-42 (1981). Investors can thus be expected to seek control of poorly managed firms, aiming to enhance returns through the curtailment of managerial rent-seeking, or improvements in the quality of management more generally. See Winter, supra note 1 , at 266 . In the face of this threat, managers will further selfregulate their choices to maximize shareholder value. See id. at 257 ("[T]o retain its position management has a powerful incentive to keep the price of stock high enough to prevent takeovers, a result obtained by making the corporation an attractive investment.").

43 See Winter, supra note 1, at 257-58, 266. 
tion of Winter's article, the corporate literature has centered its attention on the asserted linkage between state competition and the separation of ownership and control, and on the dichotomous choice between a "race to the top" versus "the bottom" in their interaction. ${ }^{44}$

Particularly striking, in fact, has been Winter's place in this discourse. Notwithstanding state competition's limited place in his substantive analysis, Winter has come to be cited as a proxy for one side of the literature's relentless "race debate." In the still-unresolved debate over whether state competition fosters a race to the bottom or the top in shareholder-managerial relations, Winter is cited-as a matter of course-to support the dominant view that state competition fosters some movement-be it a race, a "leisurely walk," 45 or a "crawl"46 - in the direction of the top. ${ }^{47}$

How did this come to be?

In large part, it can be traced to the work of Winter's successors. As Winter's economic approach to the study of corporate governance came to prevail, its advocates transmuted Winter's argument in the negative into an argument in the affirmative.48 Winter had argued that, given managerial competition, Cary was wrong to predict a race to the bottom. ${ }^{49}$ But those who followed went a step further. Rather than simply disproving Cary's argument that state competition would produce a race to the bottom, scholars who embraced Winter's basic approach-a group that gradually came to encompass almost all of

44 See infra notes 55-56 and accompanying text. Some scholars, to be sure, have been careful to tease out the distinct dynamics and normative goals at work in the operation and regulation of the modern public corporation. See, e.g., Larry E. Ribstein, Market vs. Regulatory Responses to Corporate Fraud: A Critique of the Sarbanes-Oxley Act of 2002, 28 J. CoRP. L. 1, 58 (2002) ("The state-based system of regulating corporate governance can be considered one of the main strengths of the U.S. capital markets.").

45 Ralph K. Winter, The "Race for the Top" Revisited: A Comment on Eisenberg, 89 Colum. L. Rev. 1526, 1529 (1989).

46 Michael Abramowicz, Speeding Up the Crawl to the Top, 20 Yale J. on Reg. 139, 142 (2003).

47 See, e.g., id. at $140 \&$ n.2.

48 Although Winter's argument was assuredly a defense of federalism and state competition, it is important to be clear about his precise reasoning: Winter framed his argument as a response to Cary. See Winter, supra note 1, at 255-56. More specifically, Winter's argument was presented as a refutation of Cary's suggestion of a race to the bottom, driven by charter competition among states. See id. at 255-58. So understood, Winter's essential claim was that the federalist design of corporate law need not produce a race to the bottom. See id. But this was not because of anything distinctive about federalism. Rather, it was because of the independent dynamic of competition in capital, product, and corporate control markets. See id. at 262-66. Winter's essential finding was not that federalism was good, but rather that it was not bad. See id. at 255-56; see also EASTERBrook \& Fischel, supra note 24, at 218.

49 See Winter, supra note 1 , at $255-58$. 
us $^{50}$ - cast Winter as having established the opposite of Cary's claim. ${ }^{51}$ Like Cary, Winter came to be seen as having linked state competition to shareholder-managerial relations and the separation of ownership and control. ${ }^{52}$ By contrast with Cary, however, he was said to have established a race to the top rather than the bottom..$^{53}$

More precisely, Winter's successors transformed his critique of Cary into an affirmative embrace of state competition by reading his emphasis on managerial competition out of the equation. In the modern discourse of corporate law, thus, the independent patterns of state and managerial competition successively offered up by Cary and Winter have been collapsed into one, moving us from a bifurcated account of competition to a unitary one. In an almost mathematical fashion, the conventional analysis of corporate law has dropped managers out of the equation. If states compete to meet managerial demand, and managers compete to meet shareholder demand, the logic goes, we can simply take managers out of the middle. What is left when we do so? States competing to meet shareholder demand: the corporate literature's standard linkage of state competition to the separation of ownership and control, in a race to the top. ${ }^{54}$

50 See, e.g., Abramowicz, supra note 46, at 139-41 (embracing "the increasing scholarly consensus that competition improves corporate law"); see also id. at 140 ("The corporate law literature tells a story of progress, slow but sure."). A significant majority of corporate scholars today would thus likely endorse at least some notion of capital market efficiency, some resulting pressure on managers to compete, and at least some march toward the top, however slow the climb might be and however unlikely it is to reach the acme of efficiency. See, e.g., id. at 139-41.

51 In fairness, some suggestion of the affirmative claim can be found in Winter's original article. See Winter, supra note 1, at 275-76. In later work, moreover, Winter explicitly invoked the rhetoric of a "race to the top" in corporate law. See Ralph Winter, Private Goals and Competition Among State Legal Systems, 6 HARv. J.L. \& PuB. PoL'y 127, 128-29 (1982) [hereinafter Winter, Private Goals] ("As long as Delaware is competing, there will be a race to the top."). Perhaps notably, however, Winter would thereafter step back from that claim. See Winter, supra note 45, at 1528 ("I am far more confident that Professor Cary's argument about the race to the bottom is wrong than I am that my argument that Delaware is leading a race to the top is right."). At best, he suggested, interstate charter competition might be expected to motivate a "leisurely walk" to the top. See id. at 1529.

52 See, e.g., Lucian Arye Bebchuk, Federalism and the Corporation: The Desirable Limits on State Competition in Corporate Law, 105 HARv. L. REv. 1435, 1438-49 \& nn.10-14 (1992) (discussing the traditional corporate law "race to the bottom" versus "the top" debate and its focus on state competition).

53 See id.

54 In critiquing the collapse of managerial and state competition, it bears noting that I do not mean to suggest they are unrelated. Nor do I dispute, as I explain in Part III, that each pattern of competition may contribute to the efficient operation and regulation of the modern public corporation. My only point is that in analyzing them as distinct patterns, we avoid certain pitfalls with which our analysis is presently plagued, and perhaps achieve certain new insights as well. 


\section{Misplaced Metaphor: The Limited Implications of State Competition for Corporate Governance}

In the metaphor of a "race" in corporate law, then, we have collapsed two distinct patterns of competition-among managers and among states-into a singular account of state competition. Some might see this as little more than a convenient shorthand. Yet its impact on the study of corporate law has been profound.

To begin, it has produced a literature overly focused on federalism and state competition. More importantly, it has distorted our understanding of what federalism and state competition are actually doing in corporate law. In dropping managerial competition from the equation, thus, the distinct normative ends of such competition-effective policing of the separation of ownership and control- - have instead been imputed to state competition.

The discourse of corporate law thus revolves around an understanding of state competition (and federalism more broadly) as directly tied to-and directly advancing-efficiency in shareholdermanagerial relations. In Roberta Romano's eloquent characterization, thus, federalism is "the genius of American corporate law," and hence a critical determinant of "the relations between a firm's shareholders and managers." 55 The modern study of corporate law, as such, has tied the central feature of its institutional design-federalism and state competition-to what has been its central project since publica-

55 Roberta Romano, The Genius of American Corporate Law 1 (1993). Besides the examples noted above, see supra notes 23-24 and accompanying text, additional evidence of this understanding can readily be found. See, e.g., Henry N. Butler \& Larry E. Ribstein, Opting Out of Fiduciary Duties: A Response to the Anti-Contractarians, 65 WASH. L. REV. 1, 69-70 (1990) (characterizing charter competition as directed to protecting shareholder interests); Stephen J. Choi \& Andrew T. Guzman, Choice and Federal Intervention in Corporate Law, $87 \mathrm{~V}_{\mathrm{A}}$. L. Rev. 961, 961-62 (2001); Michael E. DeBow \& Dwight R. Lee, Shareholders, Nonshareholders and Corporate Law: Communitarianism and Resource Allocation, 18 DEL. J. CORP. L. 393, 406-07 \& n.59 (1993); Fischel, supra note 41, at 921-22; Romano, supra note 15, at 217-23; Roberta Romano, Competition for Corporate Charters and the Lesson of Takeover Statutes, 61 Fordham L. Rev. 843, 846 (1993) [hereinafter Romano, Competition] ("The best assessment of the evidence is that a federal system is for the better and that Delaware's code, for the most part. benefits shareholders."); Roberta Romano, Law as a Product: Some Pieces of the Incorporation Puzzle, 1 J.L. Econ. \& ORG. 225, 279-81 (1985) [hereinafter Romano, Law as a Product]; see also Bebchuk, supra note 52, at 1439 ("[S]upporters of state competition regard it as a 'race for the top.' According to this view, charter competition drives Delaware and other states to offer rules that maximize shareholder value; consequently, the regulation of corporate affairs should be left to the states."); Arthur R. Pinto, The Constitution and the Market for Corporate Control: State Takeover Statutes After CTS Corp., 29 WM. \& MARY L. REV. 699, 716-17 n.75 (1988); Robert B. Thompson, Preemption and Federalism in Corporate Governance: Protecting Shareholder Rights to Vote, Sell, and Sue, 62 Law \& Contemp. Probs. 215, 222 (1999). 
tion of Berle and Means's seminal analysis of the modern public corporation-effective policing of the separation of ownership and control. 56

By focusing on state competition, thus, we have come to embrace a notion of the latter as promoting the quality (i.e., the substantive efficiency) of corporate governance-rather than simply enhancing the quality of corporate law. We see a direct role for state competition in advancing results properly linked-in a bifurcated account of competition-to managerial competition. State competition has thereby come to be seen as the driver in corporate law, doing the heavy lifting in advancing corporate law's central goal-efficient regulation of the separation of ownership and control.

In what follows, I question this conventional wisdom. Contrary to the familiar rhetoric of the literature, federalism and state competition should not be understood to enhance the substantive quality of corporate governance, but merely to improve the quality of corporate law. After outlining the intuition behind this conclusion, I successively consider the attempt to rescue a direct role for state competition in shaping the substantive quality of corporate governance, on the broader and narrower theories that it "facilitates" managerial competition and that it is a cost-savings device in corporate governance.

\section{A. The Distinct Ends of State and Managerial Competition}

When we tease out the distinct dynamics of state and managerial competition in the operation and regulation of the modern public corporation, familiar accounts of federalism's linkage to corporate governance prove untenable. Contrary to the conventional wisdom, state competition cannot enhance the substantive quality of shareholdermanagerial relations. Rather, it simply responds to pressure toward that end created by managerial competition. Although state competition may produce corporate law in an efficient fashion, it does not-

56 See, e.g., Romano, supra note 55, at xii ("Ever since Berle and Means, the central issue of corporate law has been how to create a legal structure that monitors management."); Stephen M. Bainbridge, The Board of Directors as Nexus of Contracts, 88 Iowa L. Rev. 1, 9 (2002); Cary, supra note 1, at 665; Fischel, supra note 41, at 916-17; Faith Stevelman Kahn, Pandora's Box: Managerial Discretion and the Problem of Corporate Philanthropy, 44 UCLA L. Rev. 579, 610 n.120 (1997); Alan R. Palmiter, Reshaping the Corporate Fiduciary Model: A Director's Duty of Independence, 67 TEx. L. Rev. 1351, 1357 n.12 (1989); Dalia Tsuk, From Pluralism to Individualism: Berle and Means and 20th-Century American Legal Thought, 30 LAw \& Soc. INQUIRY 179, 180 (2005); Winter, supra note 1, at 262 ("With a few exceptions, the legal literature is single. mindedly concerned with the discretion corporate management can exercise as a result of the 'separation of ownership and control' popularized by Berle and Means."). See generally William W. Bratton, Berle and Means Reconsidered at the Century's Turn, 26 J. CoRP. L. 737 (2001). 
unto itself-produce substantively efficient corporate governance. Stating it slightly differently, state competition may generate effective rules of corporate governance-i.e., rules that effectively advance desired substantive ends in corporate governance; it does nothing, however, to dictate those ends. ${ }^{57}$

Two hypotheticals help to highlight as much. First, consider the possibility of a centralized, national regime of corporate law. Given the primarily enabling form of existing corporate law, ${ }^{58}$ an immediate question would be whether the new regime should be mandatory or enabling in nature. .9

How might we expect Ralph Winter to respond to calls to impose mandatory rules? No need, he would likely suggest. Managers faced with enabling law will not elect rules inadequately protective of shareholder interests. To the contrary, they can be expected to choose rules consistent with shareholder interests. ${ }^{60}$ Why? "Simple," he might tell us. "See my famous article."

Managers, he would remind us, operate in three markets: capital markets, product markets, and the market for corporate control. ${ }^{61}$ Given as much, they can be expected to behave in shareholders' best interests, even in the face of (national) enabling rules. Markets work, so law should stay out of the way.

This, of course, was Winter's exact response to Cary's suggested introduction of federal minimum standards of corporate governance.

57 One might think about this point at two levels: To begin, state competition is not determinative of the quality of the content, versus the form, of the rules of corporate governance. Beyond content or form, however, it is not determinative of the real-world quality of corporate governance, given managers' need to answer to the capital markets for their actions, regardless of any discretion they might be granted by law. In a sense, the Model Business Corporation Act's distinction between "standards of conduct" and "standards of liability" might be understood in the latter light. See Charles M. Elson \& Robert B. Thompson, Van Gorkom's Legacy: The Limits of Judicially Enforced Constraints and the Promise of Proprietary Incentives, $96 \mathrm{Nw}$. U. L. Rev. 579, 582 (2002).

58 See Frank H. Easterbrook \& Daniel R. Fischel, The Corporate Contract, 89 Colum. L. Rev. 1416, 1417 (1989) [hereinafter Easterbrook \& Fischel, Corporate Contract] ("The corporate code in almost every state is an 'enabling' statute."); see also Frank H. Easterbrook \& Daniel R. Fischel, Close Corporations and Agency Costs, 38 Stan. L. Rev. 271, 279 n.15 (1986) [hereinafter Easterbrook \& Fischel, Close Corporations] ("The classic example of an enabling statute is the Delaware Code, which provides investors in both publicly and closely held corporations with a set of standard form terms which they can vary by agreement.").

59 See, e.g., Melvin Avon Eisenberg, The Structure of Corporation Law, 89 Colum. L. REV. 1461, 1524 (1989); Jeffrey N. Gordon, The Mandatory Structure of Corporate Law, 89 Colum. L. Rev. 1549, 1597 (1989).

60 See supra notes $40-42$ and accompanying text.

61 See Winter, supra note 1, at 263-64. 
Yet it applies equally to a choice between mandatory and enabling rules at the national level. Even as between law and no law, in fact, Winter's rejoinder remains exactly the same: Don't worry, efficient capital markets and resulting managerial competition will take care of it.

Now consider a second hypothetical: What quality of corporate governance would we expect to arise from state competition as we move from strong-form efficiency in the capital markets, to only somewhat efficient markets, and finally to inefficient markets? In the first case, state competition is likely to be associated with a highly efficient regime of shareholder-managerial relations. In the second, the operative dynamic of corporate governance would be only somewhat efficient. In the last, the quality of corporate governance would likely be suboptimal.

What do these hypotheticals teach us? As I read them, they suggest that the heavy lifting in determining the substantive quality of corporate governance is done not by state competition, but by efficient capital markets-and by the managerial competition Winter identified as arising out of such markets. In the first hypothetical, Winter's account of competitive efficiency plays out identically at the federal and state level, and as to any question of law. Why? Because it is simply not a question of federalism, state competition, or even law. ${ }^{62}$ In the second hypothetical, similarly, state competition proves irrelevant to the quality of corporate governance. The "genius" in American corporate governance, as such, is not the federalist organization of corporate law, but the operation of efficient markets. ${ }^{63}$

62 In a sense, this analysis might be seen to echo Bernard Black's assertion of the triviality of corporate law. See Black, supra note 14, at 543-44.

63 Given my focus on the broad dynamics of competition that undergird the modern study of corporate law, the state operates almost entirely as a black box herein. For the most part, I believe this is consistent with the analysis I hope to undertake. I acknowledge, however, the greater complexity that the unpacking of that box would entail. In particular, it is striking to consider how state litigation in corporate law would seem to speak directly to the substantive quality of corporate governance. My claim, however, is that state competition does not speak directly to the substance of corporate governance, as distinct from state law. One reconciliation of the orientation of state courts to the substantive quality of corporate governance with the argument advanced herein, then, might be the claim that state litigation of corporate law disputes involves no dimension of competition. Cf. David A. Skeel, Jr., The Unanimity Norm in Delaware Corporate Law, 83 VA. L. REv. 127, 158 (1997).

This might also help us to understand the empirical evidence that shareholder value is greater in Delaware-incorporated firms. See, e.g., Robert Daines, Does Delaware Law Improve Firm Value?, 62 J. Fin. ECON. 525, 527 (2001). The critical question, of course, is what we should understand such studies to establish. Although they suggest that the choice of Delaware law may be welfare-enhancing to shareholders, they do not tell us why. They do not establish that 
Contrary to the corporate literature's all too familiar-if often loosely offered-linkage between federalism and effective policing of the separation of ownership and control, ${ }^{64}$ then, state competition does not, in and of itself, impact the substantive implications of that separation. It does not institutionalize some invisible hand of good corporate governance. Stating it differently, state competition simply responds to the demands of market-motivated managers. Given as much, it can be expected to go no further in policing the separation of ownership and control than managers demand. It cannot, to borrow a phrase, get ahead of the market. ${ }^{65}$

The question, to be clear, is not whether state competition is beneficial to the modern public corporation. As I suggest below, it likely is. ${ }^{66}$ Instead, the question is whether state competition can improve on the allocation of decisionmaking authority and resources between shareholders and managers that is dictated by the capital markets and resulting managerial competition. Can state competition, unto itself, advance the central project of corporate law-to address the separation of ownership and control? Contrary to the rhetoric of the corporate law literature, it cannot.

Two propositions might thus be asserted: (1) State competition can do no more than managerial competition permits, and (2) more telling, state competition will do no more than what managerial competition demands. Is the relative efficiency of managerial competition important to the latter proposition? Of course it is. But inefficient capital markets and hence managerial competition do not alter the basic story. For here the first proposition comes into play. If ineffi-

state competition is the source of such welfare gains. More specifically, they do not tell us whether such increases in shareholder wealth are generated by what I characterize herein as "vertical" versus "horizontal" gains in shareholder value. State competition may be shifting surplus to the firm, and thereby generating shareholder wealth-but without regard to any enhancement in the quality of corporate governance.

64 See supra note 55 and accompanying text.

65 See infra note 71

66 See infra Part III. Further, it is not a question of whether state rules are preferable to national rules. In many areas of law, state law has been seen as preferable, in offering a wider menu of choices to relevant consumers, perhaps more effectively meeting a varied universe of demand. Neither modern theories of corporate law nor its empirical reality, however, are readily reconciled with this account. The model of state competition at the heart of corporate law analysis thus presumes a charter competition driven by similar demand curves among the universe of firms. Delaware's dominance among firms not incorporated in their home states, see Chris Brummer, Corporate Law Preemption in an Age of Global Capital Markets, 81 S. CAL. L. REV. 1067, 1082 (2008), meanwhile, suggests that diversity of corporate form is not part of the reality either. That said, state law-and even state competition-may be a source of value in corporate law in ways other than in offering a diverse choice of law. See infra Part III. 
cient capital markets produce only limited managerial competition and hence generate only limited efficiency in the allocation of decisionmaking authority and resources as between shareholders and managers, even a perfectly efficient dynamic of state competition for corporate charters can accomplish no more. ${ }^{67}$

States may well compete in ways that increase the wealth of the modern public corporation, as described below, ${ }^{68}$ but they should not be expected to compete to increase shareholder wealth, as against the interests of managers. Why, given managers' role in determining the place of incorporation, would they do so?

State competition thus cannot be expected to produce rules that are good for shareholders but bad for managers. The persistence of state antitakeover protections-the paradigmatic case of such shareholder-managerial conflict-helps to suggest as much. ${ }^{69}$ The countervailing case, of course, would be a shareholder-friendly state rule that is enacted notwithstanding seeming managerial resistance, or one that is consistently waived by promoters or managers, yet remains on the books. Neither scenario is easy to identify in the real world, or to reconcile with our prevailing theories of corporate law.

In sum, it is efficient markets and resulting managerial competition, not state competition, that are determinative of the substantive quality of corporate governance and efficient regulation of the separation of ownership and control. State competition is only as good as the managerial competition on which it relies. If efficient capital markets are effectively disciplining managers to behave in a way that optimally advances shareholder interests, then state competition can help us get there. If they are not, then it will not. If we are concerned with the separation of ownership and control, then, it is on managerial competition that we must rely. ${ }^{70}$

67 My basic proposition might alternatively be framed as follows: state competition may improve the alignment of law with managerial demand, but it does nothing to alter or shift that demand. Rather, it takes managerial interests as it finds them.

68 See infra Part III.

69 See infra Part IV.B.

70 As its point of departure, the analysis just concluded builds off the dominant view of corporate scholars of some baseline efficiency in the capital markets and some resulting pressure on managers to compete. See supra note 50. Assuming such efficiency, Part II questions the gains to be added by state competition in corporate governance. My essential argument, however, does not involve any endorsement of market efficiency. For those who would question such efficiency, thus, the argument simply emphasizes that state competition cannot serve as a surrogate mechanism for efficient regulation of the separation of ownership and control. Meanwhile, for those who would critique the quality of modern corporate governance, the argument 


\section{B. A Reinforcing Role for State Competition in Corporate Governance?}

Against this objection to the traditional linkage of state competition and the substantive quality of corporate governance, one might attempt to rescue a direct role for federalism in addressing the separation of ownership and control by insisting that state competition impacts corporate governance by reinforcing or otherwise facilitating managerial competition. State competition, in this account, reduces the barriers to managerial competition-to the effective constraint of managerial behavior by efficient capital markets. ${ }^{71}$

If the true remedy to the separation of ownership and control lies in efficient markets and resulting managerial competition, rules of corporate law that insulate managers from those markets would seem quite relevant to the substantive quality of corporate governance..$^{72}$ Antitakeover statutes are the paradigmatic example, of course, in their stifling of the market for corporate control. ${ }^{73}$ But other exam-

emphasizes that it is the inefficiency of the markets that is the appropriate target of their attack, rather than state competition. See infra Part IV.B.

71 A distinct, and more inchoate, articulation of a direct role for state competition in enhancing the substantive quality of corporate governance might characterize it as a distinct source of information on the nature of efficient governance. State competition, in this account, is a source of new information above and beyond that known to managers. Perhaps it can predict the effects of certain choices in corporate governance in ways beyond the capacity of individual managers. More poetically, perhaps it may offer insights into the "unknown unknowns" former Secretary of Defense Donald Rumsfeld made famous. See Philip Stephens, The Unwitting Wisdom of Rumsfeld's Unknowns, FiN. Times, Dec. 12, 2003, at 19 (quoting Rumsfeld press conference).

On the face of standard accounts of state competition in corporate law, there is little ground to support such a notion of state competition as "creative." Such competition responds to managerial demand, not some invisible hand of efficiency. If managers lack the ability or incentive to generate insight into relevant unknowns, state competition in corporate law-by its very nature-should do no better.

There is, to be sure, the notion of some "wisdom of crowds." See JAmes Surowiecki, THE Wisdom OF CRowds 235 (2004). Collective knowledge may thus be greater than the sum of the individual knowledge that constitutes its parts. The latter's implications for corporate law lie in the capital markets and hence the mechanisms of managerial competition, however, rather than state competition. See Ronald J. Gilson \& Reinier H. Kraakman, The Mechanisms of Market Efficiency, 70 VA. L. REV. 549, 553-54 (1984).

72 Such rules might be seen as the converse of the "market perfecting" state rules which Easterbrook sees as welcome in the marketplace of corporate law. See Frank H. Easterbrook, Managers' Discretion and Investors' Welfare: Theories and Evidence, 9 DEL. J. CORP. L. 540, 570 (1984).

73 See Lucian Arye Bebchuk \& Allen Ferrell, Federalism and Corporate Law: The Race to Protect Managers from Takeovers, 99 Colum. L. REv. 1168, 1175-76 (1999) (describing the ways in which antitakeover provisions benefit incumbent managers); see also Frank Easterbrook \& Daniel Fischel, The Proper Role of a Target's Management in Responding to a Tender Offer, 94 
ples might also be cited, including state rules that increase managers' ability to rely on retained earnings and certain forms of debt for financing, rather than returning to the capital markets. ${ }^{74}$ In the face of such rules, managers' choice of state of incorporation might be expected to impact the ability of the capital markets to police managerial behavior. If state competition reduces the incidence of such rules, then, it would seem to speak quite directly to the quality of corporate governance. ${ }^{75}$

Plausible (and perhaps familiar) as this account may sound, it is unclear precisely what it sees state competition as contributing to managerial competition, by way of reinforcement or facilitation. Let us assume, as in the prevailing account among corporate scholars, that capital markets function relatively efficiently and managers are consequently incentivized to attend to shareholder interests. ${ }^{76}$ If managers are so incentivized, they might take one of three potential approaches to antitakeover statutes or other suboptimal corporate governance rules. None depends on state competition.

First, they may elect to incorporate in a state that does not condone antitakeover protections, financing through retained earnings, or similar measures that are unduly protective of managerial interests. As noted, this line of action does not depend on state competition. It does, on the other hand, turn on federalism and the nature of corporate law as state law. Absent the latter, no alternative body of state rules would be available to properly incentivized managers. ${ }^{77}$ Two

HARv. L. Rev. 1161, 1184 (1981). But see Guhan Subramanian, A New Takeover Defense Mechanism: Using an Equal Treatment Agreement as an Alternative to the Poison Pill, 23 DEL. J. CoRP. L. $375,390-97$ (1998).

74 See Gilson, supra note 42, at 839-40. But see Winter, supra note 1, at 275-76. Mechanisms that minimize disclosure, insofar as such disclosure is seen to facilitate the operation of efficient capital markets, would be to similar effect. Cf. Bernard Black \& Reinier Kraakman, $A$ Self-Enforcing Model of Corporate Law, 109 HARv. L. Rev. 1911, 1920-21 (1996) ("Sophisticated professional accountants, elaborate financial disclosure, an active financial press, and strict antifraud provisions assure shareholders of reliable information about company performance."); Merritt B. Fox, Retaining Mandatory Securities Disclosure: Why Issuer Choice Is Not Investor Empowerment, 85 VA. L. Rev. 1335, 1379-80 (1999); see also John C. Coffee, Jr., The Mandatory/Enabling Balance in Corporate Law: An Essay on the Judicial Role, 89 Colum. L. REv. 1618, 1618 n.1 (1989) (arguing that courts should "create ex ante incentives for the disclosure of private information"). The imposition of heavier burdens on shareholders in proxy contests, finally, might also be included in this category. See Gilson, supra note 42, at 843.

75 Cf. Coffee, supra note 74 , at $1618 \mathrm{n} .1$ (counseling courts to construct fiduciary obligations of corporate law strictly, absent contractual opt-out "permit[ting] accurate pricing of the departure").

76 See supra note 50 .

77 For sake of argument, I leave aside the possibility of reincorporation overseas, notwith- 
further responses by managers motivated by the capital markets to meet shareholder demands, by contrast, do not require even that.

First, recall the default nature of modern corporate law. ${ }^{78}$ Given the latter, properly incentivized managers need not locate in a state that bars the conduct of relevant concern (e.g., antitakeover defenses or reliance on retained earnings). Rather, they can simply waive the relevant statutory authorizations in their corporate charter or bylaws. ${ }^{79}$ Here, federalism and state competition would seem to offer nothing by way of reinforcement or facilitation. Managers efficiently incentivized by the capital markets can simply impose efficient rules of corporate governance on themselves. ${ }^{80}$

Finally, and more fundamentally, if managers are motivated by the capital markets to act in the interest of shareholders, they can simply avoid the behaviors of relevant concern. They can decline, for example, to exercise takeover defenses. As Winter emphatically pointed out in highlighting the importance of managerial competition, corporate governance is not a product of law alone. ${ }^{81}$ In some sense, if managers are fully incentivized by the capital markets, it is not a product of law at all. Once we assume the efficiency of the capital markets and embrace Winter's suggestion of resulting managerial competition, managers can be expected to conform their behavior to shareholder interests regardless of what applicable state law allows. ${ }^{82}$ No reinforcement or facilitation by state competition is necessary. ${ }^{83}$

standing the increasingly real possibility of that approach. See Drawing Lines Around Corporate Inversion, 118 HARV. L. REv. 2270, 2271-72 (2005).

78 See supra note 58 and accompanying text.

79 See supra text accompanying notes 58-61.

80 I return to this possibility infra, when I consider the efficiency implications of potential national rules of corporate law. See infra Part IV.A.

81 See Winter, supra note 1 , at 262 (noting that corporations do not "[l]ive by [l]aw [a]lone").

82 See supra notes $40-43$ and accompanying text.

83 One might posit a chicken-and-egg argument here, in which state competition is essential to efficient corporate governance, assuming a certain initial state of affairs. If relevant law effectively insulates managers from the capital markets at the outset, the logic goes, state competition is needed to undermine that insulation and thereby trigger managerial competition. From there, managerial competition can take care of the rest. On several counts, I am dubious about this argument. To begin, it is difficult to reconcile with our continuing attention to federalism in corporate law, since state competition would presumably have exhausted its contribution sometime in the early 1900 s. More substantively, given the limited efficacy of antitakeover protections, as well as managers' need to compete not only in the market for corporate control but also in the capital markets and the products markets, see Winter, supra note 1, at 263-66, even managers who start off in the "insulated" jurisdiction should be under pressure to compete. As I argue below, moreover, this result does not change, even if the relevant alternative to state competition is not a state regime without competition, but instead a national regime of corporate 
But why, goes the standard rejoinder, would managers deviate from a manager-friendly rule of national application? If all managers operate under a common rule-as they might in the absence of state competition-what incentive would managers have to deviate from it? As elaborated in greater detail below, every incentive. ${ }^{84}$ Winter's managerial competition for capital thus operates not only between publicly held U.S. corporations, but among the entire universe of potential investment opportunities. ${ }^{85}$ Even if managers who accede to shareholder-value-reducing national rules do not lose capital to other publicly held U.S. corporations, consequently, they will lose it to, in Winter's words, "stock in companies incorporated in . . other countries, bonds, bank accounts, certificates of deposit, partnerships (general or limited), individual proprietorships, joint ventures, present consumption, etc." 86

Even if we acknowledge the conceptual possibility of some type of reinforcing or facilitating role, moreover, the historical performance of state competition is difficult to reconcile with such a marketreinforcing role for it in advancing effective regulation of the separation of ownership and control. To the contrary, that performance suggests just the opposite.

As described in greater detail below, there is widespread agreement that state antitakeover statutes (and related takeover protection devices) at least challenge, if they do not undermine, claims that state competition yields efficient outcomes for shareholders. ${ }^{87}$ Most scholars have recognized the threat to shareholder wealth maximization posed by antitakeover legislation, and its negative impact on the "disciplining effect of the market for corporate control on managers." 88 If federalism's particular contribution to addressing the separation of ownership and control is to be found in its impact on state rules that insulate managers from the capital markets (and hence minimize man-

law. See infra Part IV.A. Even there, managerial competition continues to exert force, assuming the operation of efficient capital markets.

84 See infra Part IV.A.

85 See Winter, supra note 1, at 257; see also supra note 42.

86 See Winter, supra note 1 , at 257 . I do not dispute that managerial competition might be somewhat more limited in the face of national versus state rules of corporate governance. Given the international equities markets, as well as alternative domestic investment vehicles, however, there is no reason to expect it to be significantly limited. See infra note 157 and accompanying text. Further, even this caveat will depend on whether some degree of competition predates the emergence of relevant national-level rules of corporate governance.

87 See infra Part IV.B.

88 See Roberta Romano, The Future of Hostile Takeovers: Legislation and Public Opinion, 57 U. Cin. L. Rev. 457, 457 (1988). 
agerial competition), then, the long persistence-and even spread-of antitakeover statutes would suggest it is not doing a particularly good job.

To the contrary, if we isolate a discrete "reinforcing" role for state competition in lowering barriers to the disciplining function of the capital markets and the market for corporate control-antitakeover protections being foremost among such barriers ${ }^{89}$-we are left with a far darker account of corporate federalism. In the most important area in which state competition might actually advance the efficient regulation of shareholder-managerial relations, the story goes, it is doing just the opposite.

The persistence and spread of state antitakeover statutes might thus be understood as managers' effort to use state competition to undermine the "genius" of the capital markets (and resulting managerial competition) in optimizing shareholder-managerial relations. In this account, state corporate law does facilitate a race-or at least a "leisurely walk" 10 - but it ends at the bottom. ${ }^{91}$ The suggestion of a direct role for state competition in determining the substantive quality of corporate governance, through its reinforcement or facilitation of managerial competition, then, would seem difficult to sustain.

\section{State Competition as Cost Savings}

A defense of the centrality of federalism in shaping corporate governance might alternatively rely on a narrower account of state competition's impact on shareholder-managerial relations. In this telling, state competition simply reduces the costs to managers of meeting shareholder demands. State competition might thus play a valuable role in reducing the costs associated with identifying, articulating, and codifying optimal rules of corporate governance. It does so, in essence, by offering a vibrant, decentralized system for generating effi-

89 As suggested above, there are other examples as well, see supra notes 73-74 and accompanying text, but state antitakeover statutes represent the most prominent, and most hotly debated, case. Given their consequently higher salience, they are appropriately viewed as a proxy for the broader dynamic at work.

90 See supra note 45 and accompanying text.

91 It accomplishes little to respond-as has become common, see, e.g., EASTERBrook \& Fischel, supra note 24 , at 223 -that state law, warts and all, is still likely to be better than federal law. My goal here is not to make any strong claim about the relative merits of state versus federal law. Rather, I am interested in the a priori question of what end result the choice of state corporate law serves. Where state law is asserted to be better than federal law, the present analysis asks: better or worse on what count? 
cient rules-here defined by their optimal regulation of the separation of ownership and control.

State competition effectively fosters, for example, the production of off-the-rack charter terms consistent with an efficient balance of shareholder and managerial power. Rather than relying on promoters or managers to modify inefficient default rules in order to achieve the optimal form dictated by the capital markets-let alone expecting them to draft contracts from scratch or seek the modification of mandatory regulations-state competition offers efficiency up on a plate. Significant cost savings can surely be expected to result, both in corporate formation and in subsequent reform, as well as in minimizing the costs of managerial lobbying for efficient rules.

Such a cost-savings account, I would argue, resonates far more closely with the framing of state competition's role that I offer herein, than with the conventional account of the corporate literature. Most significantly, it involves no direct role for state competition in enhancing the substantive quality of corporate governance. In the standard account, as described above, state competition is linked directly to the separation of ownership and control. ${ }^{22}$ In a cost-savings account, by contrast, state competition may enhance the quality of corporate law; it should not be understood, however, as directly improving the substantive quality of corporate governance. ${ }^{93}$

Besides the latter point of contrast, two additional reasons cause me to doubt that a cost-savings account can explain the corporate literature's prevailing endorsement of-and dominant emphasis onstate competition. To begin, the narrow claim of state competition as a cost-savings device would not seem to sit well with the soaring rhetoric of federalism in the literature. ${ }^{94}$ Whatever utility might lie in federalism's reduction of the transaction costs of corporate lawmaking, it would not seem to rise to the level of "genius."

Second, and related, the cost savings from state competition in corporate law is not distinctly directed to shareholder-managerial relations, the separation of ownership and control, or agency costs. A cost-savings account applies with equal force to state law governing limited liability companies and sole proprietorships as it does to the regulation of public companies. ${ }^{95}$ It is, as such, simply the story of

92 See supra notes 55-56 and accompanying text.

93 Generating good law, thus, is not the same thing as generating good governance.

94 See, e.g., Romano, supra note 55, at 1 (characterizing federalism as "[ $\mathrm{t}]$ he genius of American corporate law").

95 I do not dispute the relatively lower transaction costs of corporate re-chartering, as 
federalism generally. ${ }^{96}$ This does not make it any less significant, ${ }^{97}$ but it does make it less unique than the distinct emphasis on state competition in the corporate literature would seem to suggest.

A focus on cost savings, however, points the way to a broader account of the utility of state competition for the modern public corporation. In this account, as in the conception of state competition as a cost-savings device, the central dynamic is that of federalism generally. Although it is not a distinct story of the separation of ownership and control, however, it does tie into the core questions of corporate governance. Critically for our purposes, it acknowledges the distinct competitions among states and among managers in the operation and regulation of the modern public corporation.

\section{Federalism, State Competition, and the Horizontal Project of American Corporate Law}

Where does the foregoing leave us? Does it mark me as yet another of what many would dismiss as a race-to-the-bottom crazy, convinced that managers will take advantage of state competition to advance their interests at the expense of shareholders? Not at all. Notwithstanding the strong instinct of corporate scholars to insist that one elect one position or the other in the race debate, ${ }^{88}$ the foregoing allows room to accept-and to question-both possibilities. When we acknowledge the distinct patterns of state and managerial competition at work, the limited impact of federalism on corporate governance is readily reconciled with a cheerful account of shareholder-managerial relations.

Efficient capital markets and resulting managerial competition may well generate efficient corporate governance, entirely independent of state competition. I may have substantial doubts about interstate charter competition, whether as a theoretical or an empirical matter, but nonetheless expect managers to govern corporations in the interests of shareholders. Why? Because of the equally critical dynamic of competition among managers.

compared with the physical dislocation potentially necessary for interstate competition in certain other areas of law and regulation. The latter speaks to the relative dynamism of competition, however, not its presence or absence.

96 Cf. Edward L. Rubin \& Malcolm Feeley, Federalism: Some Notes on a National Neurosis, 41 UCLA L. REv. 903, 920-23 (1994) (suggesting capacity of federalism to enhance the quality of state regulation).

97 In fact, transaction cost savings from public production of efficient default rules may be quite substantial.

98 See, e.g., Romano, supra note 15, at 229. 
Nor does my claim of state competition's lack of direct relevance to corporate law's traditional project-efficient regulation of the separation of ownership and control-make it irrelevant to the modern public corporation. State competition's value to the firm, however, is at once narrower and broader than the standard account would imply. It is narrower than suggested by the broad claim that state competition reinforces or facilitates efficient managerial competition; yet state competition also represents something more than a mere cost-savings device in corporate governance.

Federalism and state competition should instead be understood to advance a goal entirely distinct from the separation of ownership and control-the traditional focus of corporate law. Instead of fostering efficiency in the relations of shareholder and managers within the firm, state competition is directed to the relationship of the firm as a whole with state regulators outside it. In what follows, I outline this distinct framing of the role of federalism and state competition in American corporate law.

The cost-savings function of state competition described above might thus be understood to fall within a broader account of the role of federalism and state competition in the operation and regulation of the modern public corporation. This becomes apparent when we acknowledge not only the distinct nature, but also the distinct goals, of state and managerial competition. When state competition reduces the cost of managers' efforts to provide efficient corporate governance, it should be understood as doing something entirely different than advancing the traditional separation-of-ownership-and-control project of American corporate law.

At some level, the corporate literature can be understood to appreciate as much. Yet our persistent linkage of state competition to the separation of ownership and control-most emphatically in the never-ending "race debate"-has hindered us from engaging the full implications of the distinct ends advanced by state competition. ${ }^{99} \mathrm{~A}$ more precise rhetoric of federalism would thus serve the corporate literature well. ${ }^{100}$

99 I do not mean to suggest that corporate scholars have disregarded questions of regulatory (versus managerial) efficiency. Rather, I argue that the conventional analysis has not adequately emphasized the promotion of those distinct ends by the distinct dynamics of state versus managerial competition.

100 The widely acknowledged role of state competition in the production of corporate law default rules is suggestive. It is true that state competition efficiently generates default rules; unto itself, however, it does not generate efficient default rules. 
To this end, it is useful to explore the distinct normative ends of state (versus managerial) competition. Rather than the protection of shareholders from managerial rents and inefficiencies-a dynamic internal to the firm-federalism should be understood to protect the firm as a whole ${ }^{101}$ from regulatory rents and inefficiencies that arise external to it. State competition, as such, is about the political economy of corporate law, rather than about the separation of ownership and control in corporate governance.

In its origins, Berle and Means's analysis of what they termed the "separation of ownership and control" was grounded in doubts about managerial behavior. ${ }^{102}$ For them, managerial abuse of shareholder interests was the critical challenge for the modern public corporation. ${ }^{103}$ To address this challenge, Berle and Means offered a prescription in line with their times. Coming from the pen of a committed New Dealer at the very birth of the administrative state, ${ }^{104}$ The Modern Corporation and Private Property saw public regulation as the answer. ${ }^{105}$ Such regulation, in Berle and Means's eyes, was necessary for the effective protection of shareholders against managerial depredations. ${ }^{106}$

State competition is an entirely different story, with distinct origins and distinct ends. In its genesis, enthusiasm about state competition can be traced to public choice critiques of the regulatory state in the 1960s, ${ }^{107}$ more than three decades after Berle and Means's New Deal embrace of regulation in The Modern Corporation and Private Property. ${ }^{108}$ With the work of James Buchanan and Gordon Tullock, Anthony Downs, Mancur Olson, George Stigler, and others, scholars

101 And only thereby the shareholders of the firm, as its residual beneficiaries.

102 See Berle \& MeANs, supra note 12 , at $84,115,128-40$.

103 Id.

104 See Herbert Hovenkamp, The Classical Corporation in American Legal Thought, 76 GEo. L.J. 1593, 1685 (1988) (noting that "Time magazine called The Modern Corporation and Private Property 'the economic Bible of the Roosevelt administration'" (quoting Credit Manager, Time, Apr. 24, 1933, at 14)).

105 See Berle \& Means, supra note 12, at 356.

106 Id. Almost fifty years later, of course, Winter would offer managerial competition as an alternative to such regulation, see supra notes $40-42$ and accompanying text, and both the literature and the law would follow suit.

107 See, e.g., Kenneth J. Arrow, Social Choice and Individual Values (1951); James M. Buchanan \& Gordon Tullock, The Calculus of Consent: Logical foundations of Constitutional Democracy (1962); Anthony Downs, Inside Bureaucracy (1967); Mancur Olson, The Logic of Collective Action (1965); Sam Peltzman, Toward a More General Theory of Regulation, 19 J.L. \& Econ. 211, 211-14 (1976); George J. Stigler, The Theory of Economic Regulation, 2 BeLL J. ECON. \& MGMT. SCI. 3, 3 (1971).

108 See Berle \& Means, supra note 12, at 356. 
began to challenge public interest conceptions of state regulation, including that of Berle and Means. ${ }^{109}$ Public regulators, they argued, should be seen as maximizing private utility in various familiar and idiosyncratic ways, not unlike those in the private sector. ${ }^{110}$

Corporate and securities law, far from immune to this critique, became one of its primary targets. Corporate scholars, including Henry Manne, Bill Carney, Jonathan Macey and David Haddock, and Susan Phillips and Richard Zecher, focused their attention on issues including capture of the Securities and Exchange Commission, the role of in-state interest groups in jurisdictional competition, and the utility of the securities laws' mandatory disclosure regime. ${ }^{11}$ Through such analysis, the minimization of regulatory harms to the modern public corporation emerged in its own right as a goal of corporate law. ${ }^{112}$

With this, we came to see efficiency demands as arising not only in the relationship of shareholders and managers, but in the interaction of the public corporation with its state of incorporation and other regulators as well. Rent extractions by state actors might be as likely-if not more-to impact shareholders' bottom line as managerial extractions. ${ }^{113}$

Although the latter are constrained by efficient markets and resulting managerial competition, what serves to police the former? What prevents a state from adopting ambiguous rules of corporate

109 See supra note 107 and accompanying text.

110 In the basic public choice account, regulatory "goods" are subject to supply and demand in a marketplace characterized by the self-interested behavior of legislatures, regulators and agencies, interest groups, and citizens. See Steven P. Croley, Theories of Regulation: Incorporating the Administrative Process, 98 Colum. L. Rev. 1, 34-35 (1998).

111 See, e.g., Susan M. Phillips \& J. Richard Zecher, The SEC and The Public Interest 17-25 (1981); William J. Carney, The Political Economy of Competition for Corporate Charters, 26 J. Legal Stud. 303, 303 (1997); Frank H. Easterbrook \& Daniel R. Fischel, Mandatory Disclosure and the Protection of Investors, 70 VA. L. Rev. 669, 670-71 (1984); Jonathan R. Macey \& David D. Haddock, Shirking at the SEC: The Failure of the National Market System, 1985 U. ILL. L. REv. 315, 315 (1985); Henry G. Manne, Economic Aspects of Required Disclosure Under Federal Securities Laws, in Wall Street in Transition: The Emerging System and Its Impact on the Economy 21, 25 (Henry G. Manne \& Ezra Solomon eds., 1974).

112 At least some of the shift from a discourse of shareholder protection to one of shareholder value, see, e.g., Henry Hansmann \& Reinier Kraakman, The End of History for Corporate Law, 89 GEo. L.J. 439, 439 (2001) ("[C]orporate law should principally strive to increase longterm shareholder value."); Jonathan R. Macey, Efficient Capital Markets, Corporate Disclosure, and Enron, 89 Cornell L. Rev. 394, 403 n.49 (2004), can be tied to a desire to more fully capture the range of threats to shareholder interests.

113 See Carney, supra note 111, at 303; Frank H. Easterbrook, Federalism and European Business Law, 14 INT'L REv. L. \& ECON. 125, 127 (1994); see also Romano, supra note 55, at 16-17. 
governance designed to extract rents by increasing demand for the services of in-state lawyers? What incentivizes judges and legislators to generate an optimal level of innovation versus stability in the rules of corporate law? And, in a more normatively ambiguous case, what keeps states from imposing super-competitive tax burdens on public corporations?

It is here that we find the "genius" of American corporate law.114 So long as re-incorporation is a viable option, ${ }^{115}$ federalism and resulting state competition can serve as both an impetus for effective regulation and a check on regulatory abuse. ${ }^{116}$ Thus, states that enact indeterminate rules or fail to innovate efficiently can be expected to suffer a loss in incorporations-be they re-incorporations out of state or merely a dearth of new incorporations. ${ }^{117}$ States that align their rules with the needs of relevant corporations, and their franchise taxes with the value of services they provide, by contrast, can be expected to gain business. ${ }^{118}$ In this way, a regime of state competition might even be hoped to generate a non-zero-sum enhancement of the welfare of both state and firm. ${ }^{119}$ Minimally-and perhaps more commonly-it can be expected to foster a shift of surplus from the state of incorporation and its interest groups to the firm..$^{120}$

114 Cf. Romano, supra note 55, at 1.

115 See Romano, Law as a Product, supra note 55, at 248-49. Romano observed that costs associated with re-incorporation can be high, but that

[s]till, even when the costs are toward the high end, the dollars involved are not overwhelming in comparison to the company's assets or net income. . . [C]hanging domicile is not frictionless, as the legal debate on state competition assumes, nor [is the cost] so prohibitive as to enable states to disregard the possibility of migration.

Id.; see also Black, supra note 14, at 586-89; William W. Bratton, Delaware Law as Applied Public Choice Theory: Bill Cary and the Basic Course After Twenty-Five Years, 34 GA. L. REv. 447, 454 (2000).

116 See Yingyi Qian \& Barry R. Weingast, Federalism as a Commitment to Preserving Market Incentives, 11 J. Econ. PersP. 83, 88 (1997).

117 See Black, supra note 14 , at 548 (reasoning that states "restrict[ing] corporate freedom in any important way ... will lose revenue" because corporations "will flee" to states with more liberal corporate statutes).

118 See id.; Easterbrook, supra note 113, at 126 ("The pressure of movement curtails the ability of state and local governments to impose inefficient regulations that transfer wealth to politically effective groups but injure the population at large."); see also Easterbrook, supra note 113 , at 127-28 ("When governments become sufficiently plentiful, and when the scope of laws matches the domain of their costs and benefits (that is, when costs and benefits are all felt within the jurisdiction enacting the laws), competitive forces should be as effective with governments as they are with private markets.").

119 See infra notes 121-22 and accompanying text.

120 To a related effect, efficient state corporate law may "minimize the costs to corporations of using agents to create some of the rules that control corporate behavior." See Curtis Alva, 
In this account, however, federalism is not concerned with the separation of ownership and control. It is not about managerial failure and the vertical relationship between shareholders and managers. Rather, it is about regulatory failure and the horizontal relationship between the corporation as a whole and the state. Corporate federalism thus does not speak - at least in any analytically relevant way-to the allocation of corporate surplus as between shareholders and managers within the firm. Rather, it speaks to the total size of the surplus secured by the firm from without. ${ }^{121}$ It is not, as such, about shareholders' versus managers' share of the corporate pie, but about the size of the pie in its entirety. ${ }^{122}$

Recall, once again, the role of state competition in producing default rules. ${ }^{123}$ State competition effectively aligns the incentives of state legislators and regulators with those of managers. Given as much, states can be expected to supply rules consistent with managerial demand. At least unto itself, however, state competition cannot be expected to supply rules of corporate governance that are "efficient" as measured by some extrinsic standard. Rather, if managers demand substantively inefficient rules of corporate governance, state competition will efficiently produce those inefficient rules. The utility of state competition, thus, runs not to the substantive quality of corporate governance, but to the quality of corporate law-i.e., the rules $q u a$ rules-and to the process of its generation.

To be clear, I do not doubt that the distinction I suggest is somewhat artificial. The line between the quality of corporate law and of corporate governance will often be blurry. It is nonetheless useful, however, in emphasizing the relative contributions of managerial and state competition in generating the result ultimately sought-efficient

Delaware and the Market for Corporate Charters: History and Agency, 15 DEL. J. CORP. L. 885, $890(1990)$. This is an entirely different agency, of course, than that attendant to the separation of ownership and control.

121 Again, as I discuss below, state competition might also be hoped to increase efficiency generally, with gains to both firm and state. See infra note 139 and accompanying text. The latter circumstance seems destined to be relatively rare, however, by comparison with the baseline phenomenon of a shift of surplus from state to firm.

122 Notably, this characterization of corporate federalism's role most clearly echoes the earliest scholarly explorations of interstate competition. Charles Tiebout's original analysis concerned the capacity of a decentralized political system to efficiently align the production of public goods with public demand. See Charles M. Tiebout, A Pure Theory of Local Expenditures, 64 J. Pol. ECON. 416, 416, 424 (1956). In this construct, the dependent variable of interest is state behavior-as it is in the horizontal project of corporate law I highlight. See id. Tiebout's parallel metric of efficiency thus lay in the alignment of public regulation and the demands of a mobile citizenry. See id. at 424.

123 See supra notes $58,78-80$ and accompanying text. 
governance of the modern public corporation. It calls attention, thus, to the potential to generate this result through managerial competition alone,,$^{124}$ and perhaps even within a regime of national corporate law. ${ }^{125}$

Returning to our broader frame of reference, if state competition is properly understood to promote a horizontal shift of surplus from state to firm (and perhaps, in the ideal scenario, to increase the collective wealth of both state and firm), rather than speaking to corporate law's traditional concern with shareholder-managerial relations, it is necessary to rethink the appropriate metrics for evaluating the "efficiency" of state competition in corporate law. Rather than the impact of state competition on managerial agency costs, we do better to assess its impact on relevant regulatory behavior. ${ }^{126}$

What regulatory behavior might suggest such "efficiency," at least from the vantage of the modern public corporation and its shareholders? Most apparent would be diminished franchise tax rates. ${ }^{127}$ Economic theories of jurisdictional competition thus predict a decline in marginal tax rates in the face of regulatory competition. ${ }^{128}$ At the extreme, Wallace Oates and Robert Schwab's tax theories, ${ }^{129}$ widely seen as successors to Charles Tiebout's analysis of jurisdictional competition, predict a marginal tax rate of zero, offering one potential baseline for measurement. ${ }^{130}$

As suggested above, we might also evaluate variation in the relative ambiguity of state rules in the face of competition. The indeterminacy of state corporate law has thus been argued to serve a rent

124 See supra Part II.

125 See infra Part IV.A.

126 Some attention to these metrics in the existing literature reflects an underlying appreciation of the true role of state competition in corporate law. This only makes our misleading rhetoric-and its distortive effects-even more striking.

127 As emphasized below, this metric is particularly ambiguous in its "efficiency" implications. See infra text accompanying note 139.

128 See William W. Bratton \& Joseph A. McCahery, The New Economics of Jurisdictional Competition: Devolutionary Federalism in a Second-Best World, 86 GEO. L.J. 201, 244-45 (1997).

129 See Wallace E. Oates \& Robert M. Schwab, Economic Competition Among Jurisdictions: Efficiency Enhancing or Distortion Inducing?, 35 J. PuB. ECON. 333, 336 (1988) (" $[\mathrm{J}]$ urisdictions compete for a mobile stock of capital by lowering taxes and relaxing environmental standards that would otherwise deflect capital elsewhere. In return for an increased capital stock, residents receive higher incomes in the form of higher wages. The community must, however, weigh the benefits of higher wages against the cost of foregone tax revenues and lower environmental quality.").

130 See Richard L. Revesz, Rehabilitating Interstate Competition: Rethinking the "Race-tothe-Bottom" Rationale for Federal Environmental Regulation, 67 N.Y.U. L. REv. 1210, 1240-41 (1992). 
extraction function associated with in-state legal service providers. ${ }^{131}$ Where indeterminacy increases, or even simply persists, then, competition would appear to be relatively less effective. ${ }^{132}$ Closely related to the latter, improvements in dispute resolution processes-whether purely procedural as in the timeliness of review, or more substantive as with the quality of jurists and resulting jurisprudence-would suggest a more efficient dynamic of state competition. ${ }^{133}$

Patterns of innovation in relevant jurisdictions might also be useful data points in assessing the efficacy of state competition. Relatively ready accommodation of innovations in corporate form, and perhaps in the mechanisms of corporate finance, might thus be seen as a source of competitive advantage, and hence suggestive of efficient competition. ${ }^{134}$ Conversely, as Ian Ayres has posited, over-innovation is also a possible result of active charter competition, suggesting that attempts to measure untimely or excess innovation might also be in order. ${ }^{135}$ Finally, related to such metrics of innovation, a capacity to respond efficiently to extrinsic shocks may also be an important factor in the competition among states to enhance corporate welfare, and hence a further question for evaluation. ${ }^{136}$

131 See Jonathan R. Macey \& Geoffrey P. Miller, Toward an Interest-Group Theory of Delaware Corporate Law, 65 TEX. L. Rev. 469, 505 (1987); see also Ehud Kamar, A Regulatory Competition Theory of Indeterminacy in Corporate Law, 98 Colum. L. Rev. 1908, 1911, 1932-35, 1939-40 (1998). By maintaining a certain lack of clarity in its legal rules, the state of Delaware may simultaneously reduce the ability of another state to "copy" its corporate law (by making the interpretive work of its courts an integral part of the value of its legal regime), while also increasing demand for the services of Delaware counsel. See Kamar, supra, at 1911, 1932-35, $1939-40,1946$.

132 See Kamar, supra note 131, at 1908-11.

133 See Romano, supra note 55, at 39-40. Generally, the universe of procedural features attendant to corporate law, including the ease of its amendment, the extent of relevant regulatory expertise, the capacity for effective communication, and the like, can be understood as aspects of the horizontal allocation of value between state and firm.

134 See Kahan \& Kamar, supra note 38, at 747.

135 See Ian Ayres, Supply-Side Inefficiencies in Corporate Charter Competition: Lessons from Patents, Yachting and Bluebooks, 43 U. KAN. L. REv. 541, 555 (1995).

136 Another way to think about such distinct metrics is to ask what the account I offer suggests should be our policy focus, in seeking to enhance efficiency. If more effective managerial competition is the key to enhanced corporate governance, versus more active state competition, a different set of reform proposals comes to the fore. As Todd Henderson has recently suggested:

Instead of giving the power to legislators, who know less than managers, shareholders, and creditors, why not advocate repealing the Williams Act, changing the rules about how firms repay costs in proxy battles, or any number of other reforms that would keep the burden on firm stakeholders to make these decisions.

M. Todd Henderson, The Impotence of Delaware's Taxes: A Short Response to Professor Barzuza's 'Delaware's Compensation' 6 (Univ. of Chi. Law \& Econ., Olin Working Paper No. 
As to these and other horizontal gains to the firm (and to firm and state alike) from corporate federalism, there is no conflict between shareholders and managers. State competition is not functioning to address the relationship of shareholders and managers, but to enhance the wealth of the corporation as a whole. It is, bluntly stated, agnostic as to the relations of shareholders and managers. Even as state competition shifts surplus from state to firm, it takes no position on the allocation of that surplus within the firm.

The utility of state competition is thus independent of corporate form. As noted above, gains from state competition accrue equally to a public corporation, a limited liability company, or a sole proprietorship. ${ }^{137}$ Even in the absence of any separation of ownership and control, such competition may drive down franchise taxes, improve the quality of a state's services to its chartered entities, and otherwise reduce state inefficiency and abuse. Federalism and state competition, as such, should be understood to advance entirely different ends than the traditional separation project of American corporate law.

In sum, we do well to think of distinct vertical and horizontal goals in the operation and regulation of the modern public corporation-respectively advanced by the distinct dynamics of competition among managers and among states. Most commonly, these are collapsed in the corporate literature, in ways that obscure the independent nature and normative ends of each. The former, older, and more traditional question has been the relationship of shareholder and manager, internal to the corporation. As to this vertical dynamic, the motivating project-advanced by the structure of American corporate finance, by efficient capital markets, and by managerial competitionis to minimize agency costs attendant to the separation of ownership and control. In this way, it is hoped, the surplus available to the modern public corporation may be efficiently allocated between shareholders and managers.

But there is a horizontal project as well. Here, the goal is to enhance the surplus available to the entire firm-and in the best case scenario, to both state and firm-without regard to its distribution be-

439, 2008), available at http://papers.ssrn.com/sol3/papers.cfm?abstract_id=1288769. To similar effect, the account I offer might suggest the lifting of constraints on the investment opportunities available to $401(\mathrm{k})$ and similar account holders, in the service of a more vibrant capital market and hence greater managerial competition.

137 See supra text accompanying note 95. 
tween shareholder and manager. It is in the pursuit of this distinct project that American corporate law-and the federalism and state competition at the heart of its design-reveals its true genius. ${ }^{138}$

A final note is in order, however, regarding the assessment of "efficiency" in state versus managerial competition. When we tease out the distinct normative projects advanced by managerial and state competition, there emerges a need for greater caution in evaluating the results of federalism than is suggested by the existing literature. The welfare gains to be achieved along the vertical axis of corporate governance are fairly straightforward. There, the operative goal is to maximize shareholder welfare as against managerial abuse, shirking, and the like. As to shareholder-managerial relations, consequently, there is little or no normative complexity to the gains from managerial competition.

By contrast, in the horizontal allocation of surplus between state and firm, the normative results are more ambiguous. In some cases, as noted above, federalism and state competition may encourage regulatory initiative that broadly enhances the efficiency of the relevant legal regime. ${ }^{139}$ This might be the case, for example, where state competition fosters an appropriate balance of innovation and stability in relevant regulatory rules, and likewise, where it minimizes corruption or shirking among state regulators. In such non-zero-sum circumstances, the collective wealth of both state and firm is enhanced.

More commonly, however, federalism and state competition might be understood to promote a shift of surplus from state to firm, rather than the expansion of that surplus. This, of course, is the story where interstate competition reduces franchise tax rates. Even driving marginal tax rates to zero (i.e., matching tax rates with the cost of services provided) is thus normatively ambiguous. Such matching eliminates the redistributive effects of corporate tax policy. But there is nothing inherently "efficient" in this result. Where state competition drives tax rates even lower-where states essentially subsidize in-

138 It is important to reemphasize that I do not mean to suggest that the corporate law literature has not highlighted the impact of state competition on regulatory behavior. See supra note 44. The work of William Carney, among others, might be cited as doing just that. See, e.g., Carney, supra note 111 , at 306-09. Yet the broad emphasis of corporate law remains where it has been since Berle and Means. See supra notes 55-56 and accompanying text. The motivation, as well as the basic content, of corporate law continues to be the relationship of shareholders and managers and the agency costs attendant to it. See id. Emphasis on the distinct genius of corporate federalism-not as a means to protect shareholders from managers, but as a way to protect the firm against inefficient state law-is therefore in order.

139 See supra notes $126-36$ and accompanying text. 
state incorporation - the normative ambiguity of state competition's horizontal reallocation of surplus is even clearer.

Talk of the "efficiency" of federalism and state competition in corporate law must therefore be assessed carefully. Such an assessment is beyond the scope of the present analysis. When we tease out the distinct dynamics of state and managerial competition, however, with their distinct normative ends, the importance of this assessment becomes clear. ${ }^{140}$

\section{After the Race:}

\section{The Implications of Two Competitions in Corporate Law}

In Part III, I suggested how an emphasis on the distinct competitions-and normative projects-buried within the standard account of corporate law might lead us to an altered set of metrics for the evaluation of federalism and state competition in corporate law. ${ }^{141}$ More broadly, I argue by way of conclusion, it suggests a distinct discourse of corporate law, in which there is far more for corporate scholars to talk about. Before reaching that question, however, it may be useful to note the implications of my bifurcated account of competition for some of the familiar debates of the corporate law literature.

Two questions particularly stand out. The first is the much-debated question of the appropriate role of federal law in the regulation of corporate governance. At least since Cary's proposal to introduce federal minimum standards of corporate law, ${ }^{142}$ and arguably since adoption of the federal securities laws in the $1930 \mathrm{~s},{ }^{143}$ the possibility of federal corporate law has been a topic of discussion. Attention to the distinct nature and ends of state and managerial competition has important implications for this debate. No less prominent in the literature has been the second issue I consider: the long persistence of state antitakeover protections, notwithstanding state competition. Once again, when we acknowledge the distinct roles of state and managerial competition, a distinct approach to the nature of state antitakeover protections would seem to be in order.

140 Much of the talk of state competition as a source of "efficiency" in the existing corporate literature can thus be reduced to the observation that state competition reduces the regulatory constraints on public corporations. See Ahdieh, supra note 19, at 738-41. An understanding of state competition as directed to the horizontal allocation of wealth between state and firm does not suggest such reduction to be inefficient. It highlights, however, that it is not efficient on its face.

141 See supra Part III.

142 See Cary, supra note 1 , at 701-03.

143 See Mark J. Roe, Delaware's Competition, 117 Harv. L. Rev. 588, 610-12 (2003). 
The analysis herein also has implications for other important inquiries in the corporate law literature. Consider, for example, the debate over executive compensation. ${ }^{144}$ Many have been critical of high levels of executive compensation, especially when unconnected to performance. ${ }^{145}$ In this setting, the analysis herein counsels that state competition may otherwise be functioning effectively, yet be masking failures in managerial competition. State competition may thus yield good law. It may offer necessary flexibility in compensation arrangements. It may also be efficient in excluding certain types of compensation. If managerial competition is constrained, however, suboptimal results may follow. Thus, boards may make bad choices among alternative incentive structures. Even if structures are well chosen, boards may overcompensate underperformance. If so, then federal interventions focused on state competition and resulting state law, as in Sarbanes-Oxley and other proposed measures, may be misplaced. ${ }^{146}$ Instead, the quality of relevant market efficiency and managerial competition is the appropriate target. ${ }^{147}$

144 See, e.g., William W. Bratton, The Academic Tournament Over Executive Compensation, 93 Cal. L. Rev. 1557, 1561, 1567 (2005) (reviewing Lucian Bebchuk \& Jesse Fried, Pay Without Performance: The Unfulfilled Promise of Executive Compensation (2004)); M. Todd Henderson, Paying CEOs in Bankruptcy: Executive Compensation When Agency Costs Are Low, 101 Nw. U. L. Rev. 1543, 1544-45 (2007).

145 See, e.g., Lucian Bebchuk \& Jesse Fried, Pay Without Performance: The Un. fulfilled Promise of Executive Compensation 1-10 (2004).

146 See David A. Westbrook, Notes Toward a Theory of the Executive Class, 55 Buff. L. REv. 1047, 1047 (2007).

147 More broadly, this example suggests the potential for the conventional discourse's merger of state and managerial competition to obscure relevant failures in the competitive process-including the possibility that state competition is leaving shareholders better off, without improving-or even while worsening-the central relationship in corporate governance between shareholders and managers. It may, in essence, permit managers to effectively "satisfice" shareholder demands, rather than actually secure efficient results. See Barry Schwartz, The ParADOX OF CHOICE: WHY MORE Is Less 78 (2004) ("To satisfice is to settle for something that is good enough and not worry about the possibility that there might be something better."). In a sense, this is the notion behind Lucian Bebchuk's critique of stock price studies. See Bebchuk, supra note 52, at 1449-50. Some echo of it might also be seen in Mark Roe's recent work. See Roe, supra note 143, at 595.

Consider some hypothetical values: Assuming $\$ 10$ million in corporate surplus (beyond the cost of managerial and state services), one might imagine an initial distribution of $\$ 7$ million to shareholders, $\$ 2$ million to managers, and $\$ 1$ million to the state of incorporation. Efficient state competition might be expected to disgorge the $\$ 1$ million rent extraction by the state. Even were that gain to the firm credited in its entirety to shareholders, however, it would do nothing to diminish the managerial rent extractions that are also present. If only half were passed on, meanwhile, state competition might fairly be seen as having aggravated the inefficiency in shareholder-managerial relations.

Managerial competition is thus critical to efficient results. When such competition is part of the equation, however, distinct questions arise: What is the relative efficiency of state and mana- 
Although I concentrate on the questions of federal corporate law and state antitakeover statutes, then, these should be understood as exemplary of the lessons to be derived from a bifurcated analysis of state and managerial competition. Even as to these questions, moreover, I do not attempt to offer definitive answers. Rather, I aim simply to outline the distinct approach suggested by a clearer emphasis on the role of both state and managerial competition in the operation and regulation of the modern public corporation.

\section{A. Efficient Markets, Managerial Competition, and Federal Corporate Law}

In Part III, I emphasized the role of federalism in enhancing the quality of corporate law, as opposed to the substantive efficiency of corporate governance to which it is commonly linked in the corporate literature. With its dominant orientation to the "race debate," however, the literature also makes a further error as to the contribution of federalism and resulting state competition in enhancing the quality of law.

Specifically, the collapse of state and managerial competition in the discourse of corporate law erroneously essentializes the role of federalism in fostering good rules. The standard account thus obscures the possibility of efficient regulation, even in the absence of state competition. It masks, as such, the nature of federalism as an institutional design choice, not a framework that follows inexorably from a normative commitment to efficiency. In sum, it distracts our attention from the possibility of national-yet efficient-corporate law.

As described above, managerial competition responds to shareholder demand, including in providing optimal regulation of the separation of the ownership and control. ${ }^{148}$ In the face of capital markets, product markets, and the market for corporate control, managers are incentivized to offer an attractive package of both rules and returns, sufficient to induce and maintain necessary levels of investment. ${ }^{149}$

Focusing particularly on the provision of rules, how should we understand this model to function? In the conventional account, federalism and state competition encourage states to enact default rules

gerial competition? If each operates with perfect efficiency, the entire outstanding surplus ( $\$ 3$ million, in the hypothetical offered) would be shifted to shareholders. Where state competition is relatively more efficient than managerial competition, on the other hand, the potential for one competition to mask failures in the other-as outlined above-becomes a real concern.

148 See supra notes $40-42$ and accompanying text.

149 See id.; see also Winter, supra note 1, at 263-64. 
of corporate governance in line with managerial demand. Public corporations then adopt these rules by way of their corporate charters. Nothing in the essential account of managerial competition, however, dictates this approach.

If the story of managerial competition is correct, managers are fully incentivized not simply to seek out rules that force them to govern in ways beneficial to shareholders, but to actually govern in that fashion. ${ }^{150}$ They can effectively serve shareholder interests, thus, independent of the content of any applicable law. In the face of enabling rules, managers can respond to the demands of the capital markets directly, in the design of their individual charters and bylaws. State variation-let alone competition-is unnecessary for them to do so.

One can appreciate as much by recalling my hypothetical inquiry as to managerial behavior in the face of national-level, yet still enabling, rules of corporate governance. ${ }^{151}$ If managerial competition works, as the corporate law literature widely assumes, managers should be expected to embrace those federal rules that are consistent with shareholder interests, while rejecting those that are not. To accomplish as much, any given corporation need simply alter its charter, bylaws, or both to align them with the optimal rules dictated by shareholder demand. ${ }^{152}$

This is only true, of course, if the enabling character of corporate law is independent of whether it is enacted at the state or federal level. Thus, managers can only amend their charter and bylaws to avoid inefficient rules because I assumed the presence of federal enabling law. But that, it might be argued, is a flawed assumption: there can be no such thing as rules of corporate governance that are federal, yet enabling-or perhaps even efficient more generally.

In a sense, this can be understood as a strong-form claim about federalism's connection to the separation of ownership and control. Until now, I have sought to challenge to the claim that federalism and state competition directly advance the substantive quality of corporate governance. Here, by contrast, the strengthened claim is that federal-

150 See supra notes $81-83$ and accompanying text.

151 See supra notes 58-61 and accompanying text.

152 What shareholders value, thus, is not the quality of corporate law per se, but the quality of corporate governance that arises from any given collection of rules. Assuming efficient markets, the quality of law is simply a proxy for the quality of governance. If management could evince good governance directly, or in some other indirect way (i.e., with other proxies), the results would be as efficient as having good state law, if not better. 
ism alone can produce the efficient rules dictated by managerial competition.

It is worth playing out the relevant logic: To arrive at enabling rather than mandatory corporate law, the argument goes, we need regulatory competition. The predominance of default rules in modern corporate law should thus be understood as a direct by-product of state competition. States competing for corporate charters face pressure to move from mandatory to default rules, given the necessarily lower correlation of mandatory rules with the highest level of efficiency for the greatest number of corporations. ${ }^{153}$ In this way, state competition fosters the use of default rules. In a national scheme, by contrast, such pressure would be lacking, such that mandatory rules would likely persist. ${ }^{154}$ Federalism is therefore the only viable path to enabling rules and efficient law more generally. The notion of efficient or enabling federal law is simply an oxymoron.

I am unsure this is correct. The argument offered turns on a rational choice analysis of federal regulation, ${ }^{155}$ dismissing the possibility of rules of corporate governance that are federal yet enabling, or otherwise efficient. Once we embrace that view, however, it is unclear why we would reject the similarly derived-even intertwined-possibility of regulatory capture of relevant federal agencies..$^{156}$

Consider the possibility: If we take efficient capital markets and resulting managerial competition as a given, the interest group most prone to attempt the capture of relevant federal rulemakers consists of managers seeking rules that will advance shareholder interests. ${ }^{157}$

153 State competition might thus be argued to encourage an increase in the proportion of enabling versus mandatory rules. See Jeffrey N. Gordon, Institutions as Relational Investors: $A$ New Look at Cumulative Voting, 94 Colum. L. Rev. 124, 145-46 (1994).

154 See Carney, supra note 111, at 318-19, 329 (correlating incidence of mandatory terms with less competitive climate); Note, The Case for Federal Threats in Corporate Governance, 118 HARV. L. Rev. 2726, 2732 (2005) ("Race-to-the-bottom and race-to-the-top scholars, as well as Delaware-monopoly theorists, assume that the federal government, should it choose to be involved at all, would actively create corporate law."); see also Choi \& Guzman, supra note 55, at 976-79 (arguing against a federal takeover regime, given the likelihood that the federal government would make some rules mandatory).

155 See, e.g., Douglas M. Branson, Indeterminacy: The Final Ingredient in an Interest Group Analysis of Corporate Law, 43 VAND. L. REv. 85, 108 (1990); Jill E. Fisch, Measuring Efficiency in Corporate Law: The Role of Shareholder Primacy, 31 J. CorP. L. 637, 665-66 (2006); Mark J. Roe, Delaware's Politics, 118 Harv. L. Rev. 2491, 2493-98 (2005).

156 In the latter account, of course, regulators are subject to the direct and pervasive influence of interest groups seeking rules consistent with their privately optimal regulatory agenda. See Ian Ayres \& John Braithwaite, Responsive Regulation: Transcending the Der. Egulation Debate 54-73 (1992).

157 The knee-jerk reaction of corporate scholars to this possibility might question why man- 
The likely capacity of managers to advance this agenda, further, would seem fairly substantial. Why? Because there is no obvious countervailing interest group pressure of any significance. Given efficient markets and managerial competition, thus, managers and shareholders agree on what the rules should look like. Why would federal regulators not be expected to accede to their likely well-financed demands? Or, more precisely, why would we predict that federal regulators would never do so, regardless of the operative market dynamic, institutional setting, or political economy?158

Of course, one could challenge my account of the relevant political economy, in which a national regime appears capable of producing enabling-and otherwise efficient-rules of corporate governance..$^{159}$ To wit: Congress-in contrast to state legislatures and perhaps the Delaware legislature particularly-may face too many competing demands from too many constituencies to give corporate law sufficient

agers would engage in such lobbying, given the absence of interstate competition in a national regime of corporate law. Thus, in a national regime, all public corporations face identical constraints, such that none are disadvantaged vis-à-vis their competitors by suboptimal rules. But this misses both the essential point of Winter's claim about managerial competition, see Winter, supra note 1, at 263-64, as well as the reality of modern financial markets.

Winter's argument is not about competition for capital among public corporations alone, but rather about competition for capital more generally. It is about investors' choice to invest their funds in, "among other things, stock in companies incorporated in other states or other countries, bonds, bank accounts, certificates of deposit, partnerships (general or limited), individual proprietorships, joint ventures, present consumption, etc." Id. at 257 . The rise of derivatives and other synthetic investment products, meanwhile, has rendered Winter's argument even stronger. Even if we leave non-equity investments aside, however, in an increasingly global marketplace, managers' competition now comes from overseas, perhaps even more so than from domestic competitors. Transnational competition for funds among public corporations alone may thus suffice to incentivize managers, without regard to the national versus state character of corporate law. At the margin, such competition may be slightly less vigorous than it might be, were it to include competition among U.S. equities as well. Yet this limitation may be fairly inconsequential, assuming some degree of managerial competition at the outset, preceding the introduction of any national regime of corporate law.

158 It bears reiterating that I do not argue that federalism has no role in fostering optimal rules of corporate governance. As suggested above, it likely does. See supra Part III. The argument I challenge here, however, does not simply suggest that federalism has some role to play in the development and codification of good law. Rather, the claim that efficient federal law is an oxymoron goes a step further to suggest not merely $a$ role for federalism in the creation of optimal rules, but an exclusive role.

159 Besides the conceptual argument I offer above, the possibility of federal enabling rules of corporate law may be suggested by the existence of enabling rules elsewhere in federal law, albeit in very different contexts. The Federal Arbitration Act's choice of law provisions, permitting parties to elect the application of state versus federal law, might be cited in this vein, see 9 U.S.C. $\S 9(2006)$, as well as the choice of law implicit in the nature of diversity jurisdiction, 28 U.S.C. $\S 1332(2006)$. 
attention. ${ }^{160} \mathrm{I}$ might respond, in turn, that given the largely non-conflictual interest group dynamic at work, not much attention might be needed.

Perhaps there is relatively more conflict at the federal level, though, with other groups besides managers and shareholders becoming engaged? Possibly, though it bears recognizing that even at the state level, relevant interest group politics has always included parties other than managers and shareholders; hence the asserted role of the Delaware bar in fostering indeterminacy in Delaware corporate law. ${ }^{161}$ Given as much, it is at least not obvious that interest group politics at the state level foster attentiveness to the needs of the modern public corporation in ways different in kind than in Congress. Perhaps the latter would not matter in any case, moreover, given that most federal rules would likely be generated at the regulatory level rather than by Congress anyway. And the Securities and Exchange Commission may not be much worse than Delaware. ${ }^{162}$

It is true, of course, that we would be faced with a regulatory monopolist in a national regime of corporate law, which might be inefficiently responsive for that reason, and might otherwise seek to extract monopoly rents. It is at least not self-evident, however, that Congress and the Securities and Exchange Commission would function as profit-maximizing monopolists in corporate law, given their failure to consistently do so in other settings in which they might. ${ }^{163}$ In any case, however, we would need to compare such inefficiencies and rents with the costs of competition and redundancy that we effectively avoid with the choice of national versus state rules.

There are also other potential gains from federal law, meanwhile, including the likely higher level of expertise that would arise from a pooling of resources. Thus, one might plausibly argue for national rules of corporate governance, not only when they can be shown to rest on a preferable political economy, but rather as the appropriate

160 See Kahan \& Kamar, supra note 38, at 747; Roe, supra note 155, at 2505-06, 2513-14.

161 See supra note 131 and accompanying text.

162 See Kahan \& Kamar, supra note 38, at 747. Implicit suggestions of the potential for relatively efficient regulation by the Securities and Exchange Commission can be found in the work of a diverse array of corporate law scholars. See, e.g., Donald C. Langevoort, The SEC as a Lawmaker: Choices About Investor Protection in the Face of Uncertainty, 84 WASH. U. L. REV. 1591, 1624 (2006); Roberta Romano, Empowering Investors: A Market Approach to Securities Regulation, 107 YALE L.J. 2359, 2396 (1998).

163 See Kahan \& Kamar, supra note 38, at 747. 
default, whenever they seem likely to function at least as well as the more costly dynamic of state competition. ${ }^{164}$

However this dialectical analysis of national versus state corporate law plays out in any given case, the critical point is that we are now talking-and at the right level of analysis, no less. Contrast this with the discourse that follows from the standard rhetoric of corporate law, in which federalism is the essential driver of efficiency in corporate governance, and there is consequently precious little to discuss. At least beyond an exception or two, any deviation from federalism, any intervention by federal law, is suboptimal on its face. The actual content of the Sarbanes-Oxley Act becomes largely tangential to the analysis; the critical point of analysis is that it was enacted by Congress, rather than the State of Delaware. ${ }^{165}$

Once we clarify the distinct nature, implications, and normative ends of state versus managerial competition, on the other hand, we can-nay, we must - evaluate the choice of state versus federal law on the merits in any given case. There is no longer anything per se better about state competition. There should be no rote dismissal of federal regulation, based merely on a characterization of national authorities as regulatory monopolists. ${ }^{166}$ Nor is there any reason for state law to be the default rule of choice in corporate law. ${ }^{167}$ Rather, as to any particular question, or category of questions, we must ask what reasons we have to believe that the political economy of state regulation is likely to be more or less effective than federal regulation. In any given case, given the particular political economy at work, is a state or federal rule likely to produce optimal results? ${ }^{168}$

Given the operative political economy in corporate law, then, it is quite possible that efficiency and optimality-and even the enactment

164 In the face of indeterminate evidence on the costs and benefits of state versus federal rules, the question of our operative default rule, as between state and federal corporate law, may thus be critical. Romano gives clear voice to the corporate law literature's preference for a state law default. See Romano, supra note 162, at 2383. Above, by contrast, I suggest why the costs of competition and redundancy might arguably favor a national default. Ultimately, however, my argument is properly understood as a rejection of both extremes. We should resist the easy embrace of one default versus another. We do better to interrogate the political economy of each hard case, to see where it leads us. The analysis herein is not a structural argument for national rules over state rules, as such, but a dissent from a single-minded insistence on either possibility.

165 See supra text accompanying notes 18-19.

166 See, e.g., Romano, supra note 162, at 2383.

167 See supra note 164 and accompanying text.

168 In this vein, Romano has notably acknowledged that differences in the lobbying process at the state and federal level are minimal. See Romano, supra note 162, at 2384 n.77. 
of default versus mandatory rules-can be accomplished without state competition. More notable than any particular choice of institutional design, however, is the general lesson that we must engage in a close analysis in order to make the choice between federal and state law. ${ }^{169}$ Ultimately, it is only by way of such a microanalysis of individual cases that we will be able to secure a regime of corporate law broadly directed to efficient results. ${ }^{170}$ As I have suggested elsewhere, such a regime may not be readily characterized as distinctly federal or state. ${ }^{171}$ It may be far more effective at advancing the twin ends of American corporate law, however, for that very reason. ${ }^{172}$

169 See Bratton \& McCahery, supra note 128, at 277 ("[A] plausible case for a competitive solution to a regulatory problem requires a situation-specific demonstration of both projected beneficial effects and the absence of perverse effects identified in the economic literature. Lawyerly presumptions have no place."); Kahan \& Kamar, supra note 38, at 747-48 ("[O]ur investigation points to the importance of a more rigorous, fact-based approach to regulatory competition. Neither theory nor anecdotal evidence is enough to establish the actual existence of competition. Rather than assume that jurisdictional competition exists whenever economic factors dictate that it should, one ought to search for hard evidence of actual competition. Doing so may reveal that competition in practice is far weaker than predicted."). As Michael McConnell has aptly suggested: "Often one's view of the allocation of authority for specific issues will depend on a prediction as to substantive outcomes rather than a general theory of federalism." Michael W. McConnell, Federalism: Evaluating the Founders' Design, 54 U. CHI. L. REv. 1484, 1500 (1987).

170 See Edward L. Rubin, The New Legal Process, the Synthesis of Discourse, and the Microanalysis of Institutions, 109 HaRv. L. REv. 1393, 1425-26, 1437-38 (1996).

171 See Robert B. Ahdieh, The Dialectical Regulation of Rule 14a-8: Intersystemic Governance in Corporate Law, 2 J. Bus. \& TECH. L. 165, 169-70 (2007); Ahdieh, supra note 19, at 722.

172 A final note is in order regarding the claim of this Section that national regimes may be efficient in their production of optimal (and even optional) rules of corporate governance, and that we consequently ought not essentialize the role of federalism and state competition in securing efficient results. In the text, I focus on the fact that market-motivated managers can be expected to elect optimal rules, even within a regime that is federal, yet enabling. I then outline the reasons a national enabling regime is well within the realm of the possible. But what if I am wrong? What if federal law will, of necessity, be comprised of mandatory rules? If markets remain efficient, it turns out, it ought not matter.

The collapse of state and managerial competition in the corporate law literature thus obscures a further mechanism by which optimality might be achieved in a national regime of corporate law. If we continue to assume well-functioning capital markets, managers will still be incentivized to seek efficient rules, even in the face of nationally applicable, mandatory rules of corporate governance. The latter process will necessarily involve greater bargaining and/or transaction costs, requiring managers to lobby for changes in relevant legislative or regulatory rules, or expatriate the firm's place of incorporation. (This leaves aside, of course, the possibility that managers could govern the firm efficiently, regardless of applicable law. See supra note 152.) Assuming efficient markets and resulting managerial competition, however, there is no structural barrier to efficient corporate governance, even in the face of mandatory federal law.

But why would managers bother to compete in the face of mandatory national rules? By leveling the regulatory playing field among public corporations, would such a regime not doom managerial competition? Not at all. As noted above, even dating back to Ralph Winter's seminal work, but particularly in today's global and varied capital markets, managerial competition 


\section{B. Understanding the Inefficiencies of State Antitakeover Statutes}

Among the most significant sources of contention in the "race debate" of the last three decades have been state antitakeover statutes. ${ }^{173}$ Such statutes are almost universally viewed as solicitous of managers and harmful to shareholders, as they increase the job security of the former and depress takeover premia available to the latter. ${ }^{174}$ Critics of federalism have thus cited the persistence, and even spread, of such statutes to challenge claims of efficiency in interstate charter competition. ${ }^{175}$ Enthusiasts of federalism, by way of rejoinder,

for capital is not exclusively a competition among domestic public corporations. See supra note 157. Rather, it operates across borders and over an array of investment opportunities, making competition vibrant, even in the face of mandatory national rules of corporate law. To be sure, there are significant inefficiencies in the expression of managerial competition in federal lobbying efforts or corporate inversion. I nonetheless highlight it to emphasize the possibility of active managerial competition-and resulting regulatory efficiency-even in the absence of federalism and state competition.

173 See, e.g., Cary, supra note 1, at 673-75; Winter, supra note 1, at 287-89.

174 See Lucian Arye Bebchuk \& Alma Cohen, Firms' Decisions Where to Incorporate, 46 J.L. \& Econ. 383, 404-05 (2003); Henry N. Butler, Corporation-Specific Anti-Takeover Statutes and the Market for Corporate Charters, 1988 WIS. L. REv. 365, 366; Easterbrook \& Fischel, supra note 73, at 1162-64, 1184; Romano, supra note 88, at 457; see also Amanda Acquisition Corp. v. Universal Foods Corp., 877 F.2d 496, 500 (7th Cir. 1989) (Easterbrook, J.) (acknowledging "that antitakeover legislation injures shareholders"). But see Subramanian, supra note 73, at 390-97. Some have sought to reconcile state antitakeover statutes with a salutary tale of corporate federalism by stressing that state competition is imperfect but yields efficient results with time, see Amanda Acquisition Corp., 877 F.2d at 507, that it is still preferable to federal intervention, see Romano, supra note 88 , at 503-04, or that the state competition model does not encourage and is thus not to blame for the existence of antitakeover statutes, see EASTERBROoK \& FiSCHEL, supra note 24, at 222-23. As Bebchuk and Ferrell argue, however, if antitakeover statutes were mere "fluke[s]" in an otherwise well-functioning theory of corporate federalism, we would not see the ongoing, deliberate steps leading to these statutes by both managers and state officials, who have had more than twenty years to adjust, if they felt the statutes problematic. See Bebchuk \& Ferrell, supra note 73, at 1198 . Finally, a few scholars have suggested that such statutes may actually be good for shareholders. See, for example, Lucian Arye Bebchuk, The Sole Owner Standard for Takeover Policy, 17 J. Legal STud. 197, 215 (1988):

When shareholders might be pressured into accepting an offer the rejection of which would be value maximizing, then, it might be hoped, management will use its obstructing power to block the offer. Indeed, commentators and courts recently have been using such an argument with increasing frequency to justify the use of obstructing tactics.

Id. Such claims, however, have commonly been rejected, see, e.g., EASTERBRoOK \& FischeL, supra note 24, at 220 (asserting that "it is easy to discard" the argument that antitakeover statutes "protect shareholders from the effects of 'coercive' tender offers").

175 See Bebchuk \& Ferrell, supra note 73, at 1171-72; see also John C. Anjier, Anti-Takeover Statutes, Shareholders, Stakeholders and Risk, 51 LA. L. REv. 561, 575, 580 (1991) (arguing that states' adoption of antitakeover statutes is based on fear and greed, and provides classic evidence of the "'race to the bottom' that has occurred in state corporate law since the early twentieth century"); Guhan Subramanian, The Influence of Antitakeover Statutes on Incorpora- 
have pointed to reductions in the level of resistance condoned by successive generations of state antitakeover statutes, and particularly to Delaware's authorization of only limited antitakeover protections. ${ }^{176}$

When we draw out the distinct patterns of state and managerial competition in corporate law, however, we see a very different picture. From this vantage, the persistence and spread of antitakeover statutes is not an issue of state competition at all. The existence of such statutes, which speak most directly to questions of the separation of ownership and control, is properly tied to managerial, rather than state, competition.

The persistence of state antitakeover statutes thus implicates the dynamic of competition among managers to meet shareholder demands. It directly challenges the vigor of that competition, and hence the efficiency of the capital markets that stand behind it. The real question raised by the persistence of state antitakeover statutes, then, is not why federalism and state competition are not working. Rather, it is why the capital markets are not forcing managers to eschew antitakeover protections, or at least discouraging them from seeking such protection by statute.

Advocates of federalism need not apologize for state competition, then, notwithstanding the persistence of antitakeover statutes. Their confidence in efficient capital markets and those markets' effective motivation of managers, on the other hand, may require further consideration. Those who would highlight state antitakeover statutes to condemn the status quo, by contrast, should properly direct their critique to the capital markets, rather than to state competition.

This highlights a further point about the corporate literature's analysis of state antitakeover statutes. I have already suggested the need not to dismiss federal interventions such as Sarbanes-Oxley out of hand-as much of the corporate law literature would seem to do. ${ }^{177}$ An analogous lesson might be found in the prevailing analysis of antitakeover statutes. ${ }^{178}$

tion Choice: Evidence on the "Race" Debate and Antitakeover Overreaching, 150 U. PA. L. REV. 1795, 1800-01 (2002). See generally Lyman Johnson \& David Millon, Missing the Point About State Takeover Statutes, 87 Mich. L. Rev. 846, 848-50 (1989).

176 It has thus been highlighted that Delaware has a mild statute, compared to most other states. See, e.g., Romano, supra note 162 , at 2385-86. Regardless, the critical difficulty for advocates of state competition remains: Delaware has an antitakeover statute.

177 See supra notes 18-19,165 and accompanying text.

178 Of course, beyond state law, managers' use of antitakeover protections represents a fundamental challenge to the claim of efficiency in the capital markets and in resulting managerial competition. 
As commonly taken up in the literature, state antitakeover statutes are evaluated as outliers of a sort-as exceptions to be distinguished. ${ }^{179}$ The suggestion, in essence, is of some stark conflict of shareholder and managerial interests in this particular setting. Managers are only incentivized to advance shareholder welfare, the prevailing account argues, so long as they can remain in office. ${ }^{180}$ State antitakeover statutes are thus the exception that proves the rule.

But it is unclear that antitakeover statutes can be meaningfully distinguished-and hence rendered exceptional-in this way. Recall that the motivating premise behind corporate law is the conflict between shareholders and managers, engendered by the separation of ownership and control. ${ }^{181}$ If conflict is the critical problem for state competition in the antitakeover context, then, it is hardly exceptional.

The failure of competitive efficiency in the antitakeover context, then, is an even more pressing challenge to advocates of the status quo than commonly acknowledged. Critically for our purposes, it highlights the need to carefully consider the political economy at work in distinct areas of corporate law, beyond the vague invocation of "regulatory monopolies" or one type of "race" versus another. Only by way of such a close institutional analysis may we determine the allocation of federal and state authority that will maximize the prospect of efficient regulation of antitakeover measures.

Although beyond the scope of the present work, such an analysis might begin by considering those factors that reduce the potential for efficient state-level regulation of takeovers. To begin, states may be motivated by some commitment to protect local firms, separate and apart from any interest in maximizing charter revenues. A relatively stronger misalignment of manager and shareholder interests in the takeover context, meanwhile, might also lead us to question the likely efficacy of state competition. ${ }^{182}$ Related to the latter, we might consider the relative salience of a takeover to shareholders versus manag-

179 See, e.g., Winter, supra note 1, at 287-89.

180 At some level, this is true. In the takeover context, managers' market-motivated will to advance shareholder interests must be balanced against the prospect of their displacement as managers. Yet this cannot sustain the standard distinction. Even in the context of takeovers, managerial displacement remains, in any given case, merely a possibility. Given the concomitant-and relatively greater-possibility of remaining in their positions, one would expect managers appropriately motivated by the capital markets to be fairly resistant to antitakeover statutes considered to be harmful to shareholder interests. Antitakeover statutes, then, continue to look like any other example of shareholder-managerial conflict.

181 See supra text accompanying note 22.

182 Although shareholder-manager conflict may not be unique to the antitakeover context, it may be somewhat stronger there. 
ers in assessing the potential efficacy of state rules. Finally, we might ask whether the limited effectiveness of most antitakeover measures ${ }^{183}$ could be argued to favor federal versus state rules. If antitakeover protections have little impact anyway, the argument might go, nothing is being lost with federal law, and perhaps some useful signal is sent by it.

On the other hand, the latter might also be seen to cut the other way. If little is to be gained by federal rules, perhaps they are best avoided. If one concludes that takeover events have relatively greater salience for shareholders than other corporate decisions, meanwhile, one might also see state law as likely to be fully effective in generating efficient rules. Shareholder demand may thus have a real impact in the takeover context. Finally, if one sees antitakeover law as an area in which innovation, and perhaps even variation, are especially valued, our preference for state rules ought to be concomitantly greater.

Given the particular political economy surrounding any given issue of corporate law, then, the question becomes what institutional design seems most likely to encourage the adoption of efficient rules. My claim is not that it will always be federal law. Rather, I suggest simply that it sometimes may be.

\section{Conclusion}

In Part III, I noted alternative metrics of "efficiency" that might be suggested by a move from the misplaced metaphor of a "race" in corporate governance, to an analysis of distinct competitions serving distinct normative ends. Further, in Part IV, I outlined how a focus on both state and managerial competition might impact two of the central inquiries of the corporate law literature-the possibility of federal rules of corporate governance and the implications of state antitakeover statutes. To conclude, I offer a few words about how displacement of the "race" metaphor from its current place in the corporate canon might alter the discourse of corporate law and the analytical methodologies that have come to shape it.

At a minimum, the analysis herein highlights the need for greater clarity in the rhetoric of corporate law. Yet it also has broader implications for our discourse. To begin, it counsels a shift away from the fairly absolutist terms along which discussions of corporate law have commonly proceeded. There is more institutional complexity to be

183 See Guhan Subramanian, The Disappearing Delaware Effect, 20 J.L. Econ. \& OrG. 32, 50-51 (2004). 
found in corporate governance, the foregoing discussion suggests, than suggested by the binary choice between a "race to the bottom" versus a "race to the top."

More broadly, it raises the possibility that the tail may have come to wag the dog in too much of our study of corporate law. Rhetoric may today play too central a role in driving our discourse, in lieu of close analysis. One might recall, in this vein, George Stigler's famous prediction that the discussion at academic gatherings might one day be reduced to a series of numbered arguments, known to all participants. ${ }^{184}$ "17," states the presenter. "Don't forget 3," insists the respondent. "And 7 also," a member of the audience notes, by way of clarification. Wrapping up the debate, the presenter concludes: "41." In its strong tendency toward the use, and reuse, of familiar snippets of rhetoric in its argumentation and analysis, the study of corporate law may have come to just such a cul-de-sac in its discourse.

More broadly, the analysis herein challenges us to reconsider both scholarly and practical priorities in corporate law. The corporate law literature has focused to an extraordinary degree on the nature and implications of state competition and the federal-state balance in corporate law. With this focus, however, it fails to grapple directly with the issue that it has commonly held out as the fundamental concern of the field-effective regulation of the separation of ownership and control. If the latter appropriately enjoys that priority, our focus would be better directed to managerial competition and the market efficiency that is purported to stand behind it.

Analysis of various mechanisms of informational efficiency, including but not limited to the capital markets, and of the quality of managerial competition likely to be induced by varying levels of market efficiency would thus be more to the point. It would be useful, for example, to better understand what might be characterized as the limits of informational efficiency. Does managerial competition continue to function effectively, so long as some information is available to investors? Or does its efficacy dissipate at the point when managers can consistently mislead investors? Whatever the answer, the subject is clear: these are questions of the capital markets, informational efficiency, and resulting managerial competition-not state competition. ${ }^{185}$

184 See George J. Stigler, The Intellectual and the Marketplace 39-42 (1984).

185 As noted above, regulatory constraints on the allocation of $401(k)$ and similar funds might also deserve scrutiny from the vantage of a managerial versus state competition-driven account of the mechanisms of efficiency in corporate governance. See supra note 136 . Such 
This, of course, may be difficult for legal scholars to concede. If the separation of ownership and control truly is the signature question of American corporate governance, thus, law necessarily moves to the background, in both the operation and the resulting analysis of corporate governance. Try as we might to avoid it, however, this was Winter's critical insight. Corporations, he insisted, do not "[1]ive by [1]aw [a]lone."186 The choice thus becomes clear. If the separation of ownership and control is our priority, capital markets should be our focus. Of course, we might alternatively highlight the horizontal project described above as the point of corporate law-though that might be no less difficult an adjustment. In any case, some shift away from a dominant orientation to federalism and state competition would seem essential. ${ }^{187}$

Beyond academia, the real world of corporate law faces an analogous question of priorities. What, in sum, should be the function of corporate law and regulation? I have described two discrete processes of competition, which serve distinct normative ends in the operation and regulation of the modern public corporation. In the design and evolution of corporate law regimes, should one or the other take precedence? Should our scheme of corporate and securities law be primarily directed to constraining managerial failures or avoiding regulatory failures? Of course, there is wisdom here in King Solomon's approach: both should be priorities. Given at least potential deviations in the optimal regime suited to each goal, however, some choices may be unavoidable.

The most important implications of the analysis herein, however, do not turn on the horizontal or vertical patterns of efficiency I highlight, or any particular conclusions I offer about them. I am prepared to concede, for example, the possibility that federalism may contribute to corporate governance in ways beyond the shift of surplus from state

constraints, in essence, diminish the extent to which the full breadth of the capital marketsincluding those investments not permitted under existing regulations-can function to encourage effective managerial competition. This result is likely to be particularly harmful, of course, in those spheres in which national-level rules are in force, and direct competition among U.S. equities is consequently more limited.

186 See Winter, supra note 1 , at 262.

187 One might particularly question the continuing emphasis on federalism in the corporate law literature, given the increasing popularity of distinct business forms, including limited liability companies and limited partnerships. See, e.g., David Carey \& John E. Morris, Blackstone Commands Top Dollar, The Deal.com, June 22, 2007, www.thedeal.com (search "Blackstone Commands Top Dollar"). As to these business forms, the internal structure of the firm, as well as the nature of its capital-raising activity, raise questions likely to be overlooked with a continuing emphasis on federalism. 
to firm. Thus, the signaling functions of a firm's choice of state of incorporation may be important as a purely heuristic matter, independent of the content of the consequently applicable rules of corporate law. To go down this path, we would need to think in more behavioral terms about patterns of market efficiency than we commonly have. Yet that might have its place in a more vibrant discourse of corporate law.

The most critical implications of my analysis, as such, are about the nature of our discourse. The fact of having something to talk about in corporate law is thus significant. Between the binary mode of analysis that has shaped the form of the corporate law discourse, and the single-minded orientation to federalism and state competition that has defined its content, we have been left with far too little to discuss. In the "race debate," thus, analysis was reduced to a stark choice between opposed conclusions on a single question, leaving little room-or even need-for discussion. You were either with us or against us.

Once we distinguish the independent dynamics of state and managerial competition at work in American corporate law, however, and further identify the distinct ends advanced by each, the nature of the discourse of corporate law must necessarily shift. Critically, we must acknowledge the lack of any singular institutional implication of a belief in capital market efficiency. Although the vast majority of corporate scholars have at least some confidence in both managerial and state competition, ${ }^{188}$ nothing precludes confidence in the former, but not the latter. Efficient capital markets can thus be fully reconciled with the federalization of corporate law. Even the converse, in fact, is viable: one might question the efficiency of the capital markets, yet expect state competition to yield efficient results as to the distinct horizontal project attendant to the relationship of state and firm.

Rather than simply dismissing federal rules of corporate law as suboptimal on their face, then, advocates of state law must offer a coherent and case-specific account of the operative political economy that supports that conclusion. ${ }^{189}$ Instead of simply rejecting SarbanesOxley because it is federal law, close analysis is necessary. Advocates

188 See supra notes 50, 70.

189 Cf. Bratton \& McCahery, supra note 128, at 277 (calling for a "situation-specific demonstration" of the basis for regulatory competition); Kahan \& Kamar, supra note 38, at 747-48 ("Rather than assume that jurisdictional competition exists whenever economic factors dictate that it should, one ought to search for hard evidence of actual competition."); McConnell, supra note 169 , at 1500 ("Often one's view of the allocation of authority for specific issues will depend on a prediction as to substantive outcomes rather than a general theory of federalism."). 
of federal rules, by a similar token, cannot simply invoke a mantra of "shareholder protection," but must offer their own account of the political economy at work. With such a heightened dialectic, we may move toward real genius in American corporate law, and perhaps even foster a race to the top. ${ }^{190}$

Tied to this more vibrant discourse of corporate law, a final implication of the foregoing concerns the inadequate attention of the corporate law literature to matters of institutional design. This has begun to change, with increasingly complex accounts of the dynamics at work in American corporate law. Mark Roe's hypothesis that Delaware is motivated by some sense of competition with the federal government is suggestive of this trend. ${ }^{191}$ Nonetheless, that Roe's insight - a fairly self-evident one, at heart-was greeted as so radical a departure from the prevailing wisdom (and not uncommonly condemned as such) ${ }^{192}$ suggests how far the scholarship has yet to go.

More particularistic studies of federalism's impact in corporate law are therefore essential. Through a microanalysis of the varying political economies at work in different areas of corporate law, our analysis may move to a new level. ${ }^{193}$ Broadly, we may better understand cases in which institutions - the Delaware courts being the most commonly cited example-are more important than the rules. ${ }^{194}$ When we engage in such analysis, moreover, we can appreciate that there is nothing per se better about state competition; yet we will equally see that there is nothing per se worse about it. When we move beyond the dichotomous metaphor of "top" and "bottom" in corporate law and engage in a more meaningful institutional analysis of federalism in corporate law, thus, we may discover room to question it, without dismissing it out of hand.

Ultimately, such a microanalysis of institutions holds great promise for the corporate law literature. If we seek to understand the true place of federalism in the operation and regulation of the modern

190 As Donald Langevoort has aptly suggested of the Securities and Exchange Commission: "[Its] workings . . . are far more complicated than most of either its critics or enthusiasts portray . . . " Langevoort, supra note 162, at 1626. Given such complexity, "we need much deeper institutional study motivated by neither doubt nor enthusiasm." Id.

191 See Roe, supra note 143, at 590 (arguing that "chief competitive pressure comes not from other states but from the federal government").

192 See Romano, supra note 15, at 223-24.

193 See Rubin, supra note 170 , at 1425.

194 See Romano, supra note 55, at 39-40. 
public corporation, such analysis will serve us in far greater stead than continued debate over the direction and speed of various "races" in corporate law. 